University of Nebraska - Lincoln

DigitalCommons@University of Nebraska - Lincoln

Agronomy \& Horticulture - Faculty Publications

Agronomy and Horticulture Department

2021

\title{
Improving publicly available corn nitrogen rate recommendation tools with soil and weather measurements
}

\author{
Curtis J. Ransom \\ USDA ARS, Columbia, MO, Curtis.Ransom@usda.gov \\ Newell R. Kitchen \\ USDA ARS, Columbia, MO, newell.kitchen@usda.gov \\ John E. Sawyer \\ lowa State University, jsawyer@iastate.edu \\ James J. Camberato \\ Purdue University, jcambera@purdue.edu \\ Paul R. Carter \\ Clive, IA
}

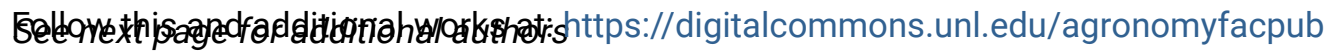

Part of the Agricultural Science Commons, Agriculture Commons, Agronomy and Crop Sciences

Commons, Botany Commons, Horticulture Commons, Other Plant Sciences Commons, and the Plant

Biology Commons

Ransom, Curtis J.; Kitchen, Newell R.; Sawyer, John E.; Camberato, James J.; Carter, Paul R.; Ferguson, Richard; Fernández, Fabián G.; Franzen, David W.; Laboski, Carrie A.M.; Myers, D. Brenton; Nafziger, Emerson D.; and Shanahan, John F., "Improving publicly available corn nitrogen rate recommendation tools with soil and weather measurements" (2021). Agronomy \& Horticulture -- Faculty Publications. 1453.

https://digitalcommons.unl.edu/agronomyfacpub/1453

This Article is brought to you for free and open access by the Agronomy and Horticulture Department at DigitalCommons@University of Nebraska - Lincoln. It has been accepted for inclusion in Agronomy \& Horticulture -Faculty Publications by an authorized administrator of DigitalCommons@University of Nebraska - Lincoln. 


\section{Authors}

Curtis J. Ransom, Newell R. Kitchen, John E. Sawyer, James J. Camberato, Paul R. Carter, Richard

Ferguson, Fabián G. Fernández, David W. Franzen, Carrie A.M. Laboski, D. Brenton Myers, Emerson D.

Nafziger, and John F. Shanahan 


\title{
Improving publicly available corn nitrogen rate recommendation tools with soil and weather measurements
}

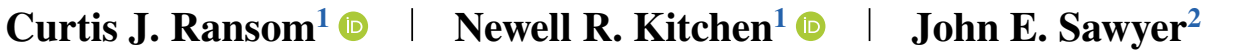 \\ Paul R. Carter ${ }^{4} \quad$ Richard B. Ferguson ${ }^{5} \quad$ Fabián G. Fernández ${ }^{6}$ \\ David W. Franzen ${ }^{7}$ () | Carrie A. M. Laboski ${ }^{8}$ \\ D. Brenton Myers 9 \\ Emerson D. Nafziger $^{10}$ (c) | John F. Shanahan ${ }^{11}$ \\ ${ }^{1}$ USDA-ARS Cropping Systems and Water Quality Research Unit, 243 Agric. Eng. Bldg., Columbia, MO 65211, USA \\ ${ }^{2}$ Iowa State Univ., 3208 Agronomy Hall, Ames, IA 50011, USA \\ ${ }^{3}$ Purdue Univ., Lilly 3-365, West Lafayette, IN 47907, USA \\ ${ }^{4}$ Independent Agronomist, 13801 Summit Dr., Clive, IA 50325, USA \\ ${ }^{5}$ Univ. of Nebraska, Keim 367, Lincoln, NE 68583, USA \\ ${ }^{6}$ Univ. of Minnesota, 1991 Upper Buford Circle, St. Paul, MN 55108, USA \\ ${ }^{7}$ North Dakota State Univ., PO Box 6050, Fargo, ND 58108, USA \\ ${ }^{8}$ University of Wisconsin-Madison, 1525 Observatory Dr., Madison, WI 53706, USA \\ ${ }^{9}$ Corteva Agriscience, 8325 NW 62nd Ave., Johnston, IA 50131, USA \\ ${ }^{10}$ Univ. of Illinois, W-301 Turner Hall, 1102 S. Goodwin, Urbana, IL 61801, USA \\ ${ }^{11}$ Soil Health Institute, 6807 Ridge Rd, Lincoln, NE 68512, USA
}

James J. Camberato ${ }^{3}$

\section{Correspondence}

Curtis J. Ransom, USDA-ARS Cropping Systems and Water Quality Research Unit, 243 Agric. Eng. Bldg., Columbia, MO, 65211, USA.

Email:Curtis.Ransom@usda.gov

\section{Associate Editor: Olga S Walsh}

Disclaimer Any mention of commercial names or products is for information only and does not denote a recommendation or endorsement by the authors.

\begin{abstract}
Improving corn (Zea mays L.) $\mathrm{N}$ fertilizer rate recommendation tools is necessary for improving farmers' profits and minimizing $\mathrm{N}$ pollution. Research has repeatedly shown that weather and soil factors influence available $\mathrm{N}$ and crop $\mathrm{N}$ need. Adjusting available corn $\mathrm{N}$ recommendation tools with soil and weather measurements could improve farmers' ability to manage $\mathrm{N}$. The aim of this research was to improve publicly available $\mathrm{N}$ recommendation tools with site-specific soil and weather measurements. Information from 49 site-years of $\mathrm{N}$ response trials in the U.S. Midwest was used to evaluate 21 rate recommendation tools for a single (at-planting) and split (at-planting + sidedress) $\mathrm{N}$ application. Using elastic net and decision tree algorithms, the difference between each tool's $\mathrm{N}$ recommendation and the economically optimum nitrogen rate (EONR) was modeled against soil and weather measurements. The model's predicted values were used to adjust the tools. Unadjusted the best performing tool had $r^{2}=.24$; after adjustment, the best performing tool had $r^{2}=.57$. Overall tool improvement was modest and sometimes required many
\end{abstract}

\footnotetext{
Abbreviations: AWDR, abundant and well-distributed rainfall; BD, bulk density; cEONR, reasonably close to economically optimal nitrogen rate; CHU, corn heat units; EONR, economically optimal nitrogen rate; GDD, growing degree days; LSNT, late-spring soil nitrate test; MRTN, maximum return to nitrogen; OM, organic matter; PPNT, pre-plant soil nitrate test; PPT, total precipitation; PSNT, pre-sidedress soil nitrate test; SDI, Shannon diversity index; SI, sufficiency index; TC, total carbon; TIC, total inorganic carbon; YG, yield goal 
additional inputs. Using weather measurements (e.g., evenness of rainfall or abundant and well-distributed rainfall) helped increase $\mathrm{N}$ recommendations by accounting for $\mathrm{N}$ loss while soil measurements (e.g., $\mathrm{pH}$ and total $\mathrm{C}$ ) helped decrease $\mathrm{N}$ recommendations when there was sufficient available soil $\mathrm{N}$. This investigation showed that incorporating soil and weather measurements is a viable approach for improving corn $\mathrm{N}$ recommendation tools regionally; but even with adjustments, tools still have room for additional improvement.

\section{1 | INTRODUCTION}

Nitrogen management in cereal crop production seeks to maximize profits and minimize the risk of $\mathrm{N}$ losses that contribute to environmental issues. One key performance goal is to apply $\mathrm{N}$ fertilizer at rates close to the economically optimal nitrogen rate (EONR) (Bandura, 2017; Hong et al., 2007; Kyveryga et al., 2009). Yet EONR varies annually, and $\mathrm{N}$ recommendation tools do not consistently recommend rates close to the EONR (Ransom et al., 2020; Schmidt et al., 2009; Tao et al., 2018). Predicting EONR values at the time of an $\mathrm{N}$ application is difficult as EONR can differ within a field and from year to year (Kyveryga et al., 2009; Scharf et al., 2005; Shanahan et al., 2008). Both the spatial and temporal variability of EONR are driven by environmental (e.g., soil texture, soil water-holding capacity, and rainfall distribution), genetic (e.g., hybrid and stress tolerance traits), management practicies (e.g., $\mathrm{N}$ form, placement, timing, rate, previous crop, manure history), and their interactions (Dinnes et al., 2002; Kay et al., 2006; Moebius-Clune et al., 2013; Schmidt et al., 2009; Zhu et al., 2009).

Of all the $\mathrm{N}$ recommendation tools available, only the crop growth model approach integrates many of the genetic, environment, management factors, and their interactions ( $\mathrm{G} \times \mathrm{E} x$ $\mathrm{M})$ to make a site-specific $\mathrm{N}$ recommendation (Morris et al., 2018). But most crop growth model-based tools available to farmers require extensive parameter inputs, training (Puntel et al., 2018), or are commercially based (e.g., Adapt-N and Granular's Encirca Services) and require a service fee limiting their widespread adoption by farmers (Melkonian et al., 2008; Morris et al., 2018). Also, many of the publicly available recommendation tools consider only a few of the $\mathrm{G} \times \mathrm{E} x$ $\mathrm{M}$ factors. For example, canopy reflectance sensing uses visible and near-infrared wavelengths to estimate the $\mathrm{N}$ status of plants as a function of the plant's color and biomass (Kitchen et al., 2010). While canopy sensing works by integrating all abiotic and biotic factors that affect $\mathrm{N}$ status in the plant, it does not account for the potential soil $\mathrm{N}$ supply or conditions leading to $\mathrm{N}$ loss and plant $\mathrm{N}$ stress after the time of sensing. Other $\mathrm{N}$ recommendation tools were derived from empirical data across years, $\mathrm{N}$ rates, hybrids, and cropping systems but ignore the seasonal differential or complexity of $\mathrm{G} \times \mathrm{E}$ x M. These include soil nitrate tests (e.g., pre-plant nitrate test [PPNT], pre-sidedress nitrate test [PSNT], and late-spring nitrate test [LSNT]), and empirical-based models (e.g., yield goal-based recommendations [YG] and maximum return to nitrogen [MRTN]) (Morris et al., 2018).

A recent evaluation of 31 publicly available $\mathrm{N}$ recommendation tools showed that across eight states of the U.S. Midwest, no one tool performed exceptionally well across a wide range of growing conditions (Ransom et al., 2020). To improve these tools, additional G x E x M factors should be considered. One approach for improvement is to modify current $\mathrm{N}$ recommendation tools using site-specific soil and weather measurements. Soil and weather measurements correlate well with corn (Zea mays L.) response to $\mathrm{N}$ fertilizer (Tremblay et al., 2012) as they drive seasonal $\mathrm{N}$ mineralization and $\mathrm{N}$ losses. Using proven ensemble learning methods, multiple weak predictors (i.e., tools, soil, weather) could be combined for a more accurate prediction of EONR. One example of ensemble learning that was successful at improving a few $\mathrm{N}$ recommendation tools was boosting (Bean et al., 2018; McDaniel et al., 2020; Ransom et al., 2019). Boosting works as a forward adaptative model, where an initial model is improved by fitting a new function to the residuals of the prediction (e.g., difference between tool's recommendations and EONR). Using this method more publicly available $\mathrm{N}$ recommendation tools could be improved.

The primary objective of this investigation was to improve publicly available corn $\mathrm{N}$ rate recommendation tools by integrating soil and weather information. An expected outcome of this evaluation is identifying soil and weather measurements most helpful in improving recommendations. We expect that $\mathrm{N}$ recommendation tools will more accurately estimate EONR across the U.S. Midwest after accounting for site-specific soil and weather measurements.

\section{2 | MATERIALS AND METHODS}

\section{1 | Experimental design}

This research was conducted as a part of a public-private collaboration between Corteva Agriscience and eight U.S. 
Midwest universities (Iowa State University, University of Illinois Urbana-Champaign, University of Minnesota, University of Missouri, North Dakota State University, Purdue University, University of Nebraska-Lincoln, and University of Wisconsin-Madison). Each state conducted research on two sites each year from 2014 to 2016, with a third site in Missouri in 2016, totaling 49 site-years (Figure 1). About half the sites were on farmers' fields and the other half on University research stations. All states followed a similar protocol for plot research implementation including site selection, weather data collection, soil and plant sample timing and collection methods, plot dimensions, $\mathrm{N}$ application timing, $\mathrm{N}$ source, and $\mathrm{N}$ rates with specific details described in Kitchen et al. (2017). Treatments included four replications of ammonium nitrate fertilizer rates between 0 and $315 \mathrm{~kg} \mathrm{~N} \mathrm{ha}^{-1}$ in $45 \mathrm{~kg} \mathrm{~N} \mathrm{ha}^{-1}$ increments applied either in a single (atplanting) application or a split application to where $45 \mathrm{~kg}$ $\mathrm{N} \mathrm{ha}^{-1}$ was surface broadcast at-planting and the remaining fertilizer $\mathrm{N}$ was broadcast at the $\mathrm{V} 9$ corn developmental stage (Abendroth et al., 2011).

\section{2 | Determining the economically optimal nitrogen rate}

Grain yield response to $\mathrm{N}$ fertilizer rates was used to calculate the EONR at each site by fitting a quadratic or quadratic-plateau to all four replicates (Cerrato \& Blackmer, 1990; Scharf et al., 2005). Economically optimal $\mathrm{N}$ rate values were calculated for all $\mathrm{N}$ fertilizer applied in a single at-planting application (hereafter referred to as "single $\mathrm{N}$ application"), and $\mathrm{N}$ split applied between planting and a sidedress application (hereafter referred to as "split $\mathrm{N}$ application"). The cost of $\mathrm{N}$ was US $\$ 0.88 \mathrm{~kg} \mathrm{~N}^{-1}$, and the price of corn was $\$ 0.158 \mathrm{~kg}_{\text {grain }}{ }^{-1}$ (equivalent to $\$ 0.40 \mathrm{lb} \mathrm{N}^{-1}$ and $\$ 4.00 \mathrm{bu}^{-1}$ ). The EONR was capped at the maximum $\mathrm{N}$ rate ( $315 \mathrm{~kg} \mathrm{~N} \mathrm{ha}^{-1}$ ). For additional details refer to Kitchen et al. (2017). Five of the seven irrigated sites had $\mathrm{N}$ applied through irrigation between 1 and $53 \mathrm{~kg} \mathrm{~N} \mathrm{ha}^{-1}$, which was included in determining the EONR of those sites. For 19 of the 49 sites, the single and split EONR values were similar because the difference in return to $\mathrm{N}$ at EONR between $\mathrm{N}$ timings was within $\$ 2.50 \mathrm{ha}^{-1}$ (Bandura, 2017). Thus, for these sites the EONR used was the average of the two timings. The EONR results were used as the standard for evaluating the $\mathrm{N}$ rate recommendation tools used or developed in this study.

\section{3 | Nitrogen recommendation tools evaluated}

Publicly available corn $\mathrm{N}$ recommendation tools evaluated for improvement included only those that previously did not

\section{Core Ideas}

- Tested two methods for improving 21 different corn $\mathrm{N}$ recommendation tools.

- Majority of tools improved by incorporating weather and soil measurements.

- Best unadjusted tool had an $r^{2}=.24$, with adjustments best tool had $r^{2}=.57$.

have a negative linear relationship with EONR (Ransom et al., 2020). The reason for this focus was because other research showed tools with a negative linear relationship with EONR were not substantially improved when modified with soil and weather information (Ransom et al., 2019). As such, tools included in this analysis (i.e., no or a positive linear relationship with EONR) are listed in Table 1. Tools were evaluated for a single (at-planting) and a split (at-planting + sidedress), when applicable, $\mathrm{N}$ application.

For a brief description of $\mathrm{N}$ recommendation tools' methodology see Table 1. Any additional steps or calculations used to determine a tool's $\mathrm{N}$ recommendation are found below.

\section{4 | Yield goal}

All yield goal (YG) tools required an expected yield. The expected yield for each site was determined using the average of the previous 5-yr county corn yields for the county where the site was located. The expected yield was then increased by 10,20 , or $30 \%$ for low, medium, and high productive soils, respectively. The soil productivity was determined using the site's predominantly mapped soil, similar to that done by Laboski and Peters (2012). This procedure classifies soil productivity as either low, medium, or high using soil texture, drainage class, depth to bedrock, available water capacity in the upper $1.50 \mathrm{~m}$ of soil, average growing degree days, irrigation, and artificial tile drainage.

\section{5 | Soil nitrogen tests}

For pre-plant soil nitrate test (PPNT) tools, soil samples were obtained in the spring before any $\mathrm{N}$ fertilizer applications. Ten cores were taken with a hand-probe and combined to represent each block to a depth of $0.90 \mathrm{~m}$, separated in $0.30 \mathrm{~m}$ increments. Samples were air or oven-dried $\left(\leq 32{ }^{\circ} \mathrm{C}\right)$ depending on the state within $12 \mathrm{~h}$ of sampling. If samples could not be immediately dried, they were frozen or refrigerated until samples could be dried and processed. Dried samples were crushed with a flail-type grinder, passed through a 2-mm 


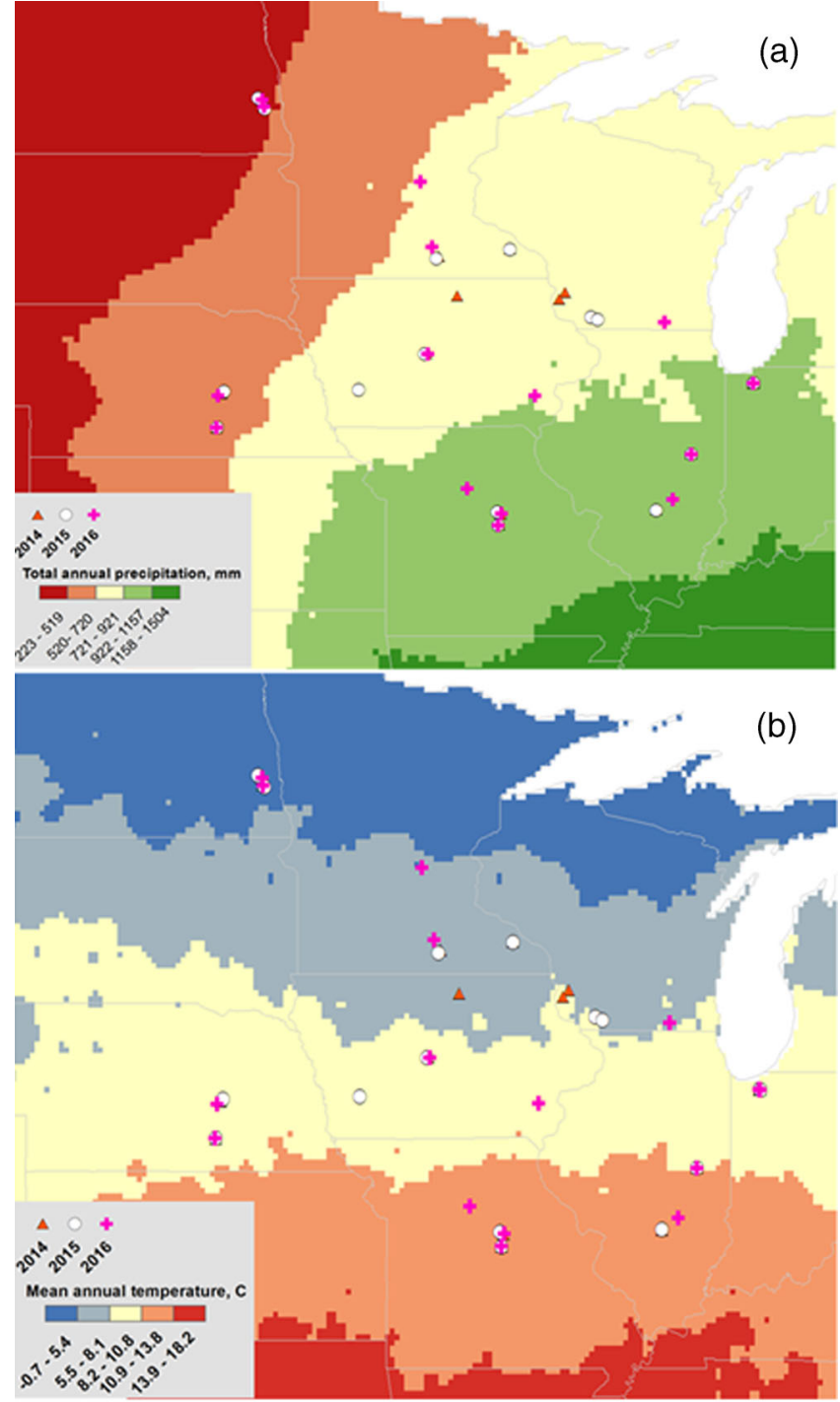

F I G U R E 1 U.S. maps depicting the spatial distribution of (a) mean annual rainfall from the National Severe Storms Lab (NOAA), and (b) mean annual temperature. The location of the 49 study sites from 2014 to 2016 within the eight states Iowa, Illinois, Indiana, Minnesota, Missouri, Nebraska, North Dakota, and Wisconsin are also overlaid on each map. This figure was adapted from Kitchen et al. (2017)

sieve, and homogenized before sending to Agvise Laboratories for soil nitrate- $\mathrm{N}$ analysis. A 7.65-g soil sample was mixed with $19.13 \mathrm{ml}$ of $0.2 \mathrm{M} \mathrm{KCl}$, shaken for $>5 \mathrm{~min}$, filtered, and soil nitrate-N determined using the Cadmium Reduction method (Gelderman \& Beegle, 1998) with a modified Technicon AutoAnalyzer (SEAL Analytical, Inc.). A site's soil nitrate-N was used in the PPNT tools' recommendations by averaging soil nitrate- $\mathrm{N}$ values of all four blocks. Two of the 49 sites lacked PPNT data, so this tool was tested using 47 of the 49 sites.

For pre-sidedress soil nitrate test (PSNT) tools, soil samples were obtained at the V5 \pm 1 corn development stage
(Abendroth et al., 2011) from plots that received either 0 or $45 \mathrm{~kg} \mathrm{~N} \mathrm{ha}^{-1}$. Each plot's soil sample was a composite of six cores taken with a hand-probe down to a depth of $0.60 \mathrm{~m}$, separated in $0.30-\mathrm{m}$ increments. The same sample preparation and analysis protocols were followed as described for the PPNT samples. Each PSNT/late-spring soil nitrate test (LSNT) tool was evaluated using a site average of measured nitrate- $\mathrm{N}$ from plots that received either 0 or $45 \mathrm{~kg} \mathrm{~N} \mathrm{ha}^{-1}$ at planting. These are noted as PSNT/LSNT 0 and PSNT/LSNT 45 , respectively.

\section{6 | Maximum return to nitrogen}

The maximum return to nitrogen (MRTN) recommendations for all site-years were determined by using values obtained in 2016, as only a few states had updated the MRTN database during the $3 \mathrm{yr}$ of this project. The MRTN values for Iowa, Illinois, Indiana, Minnesota, and Wisconsin were obtained from the online Corn N Rate Calculator (cnrc.agron.iastate.edu; verified 5 Mar. 2017). The MRTN values for North Dakota were obtained from the North Dakota Corn Nitrogen Calculator (www.ndsu.edu/pubweb/soils/corn; verified 5 Mar. 2017). The price of corn/ $\mathrm{N}$ fertilizer ratio used was 5.6:1 (US\$ per kg grain and US\$ per kg N) (or 10:1 using US\$ and bushel or lb units). Since neither Missouri nor Nebraska had a compiled database supporting the MRTN approach, sites from these states were excluded ( $n=13)$ from this tool's evaluation.

\section{$2.7 \quad$ Canopy reflectance sensing}

Canopy reflectance sensing measurements using the RapidSCAN CS-45 (Holland Scientific) were collected concurrently with split $\mathrm{N}$ applications (i.e., $\pm 2 \mathrm{~d}$ of split $\mathrm{N}$ application). For most sites, this occurred at the $\sim \mathrm{V} 8-\mathrm{V} 10$ corn development stage. Measurement details are described in Kitchen et al. (2017). The Holland and Schepers algorithm (HS) (Holland \& Schepers, 2010) was used to calculate a $\mathrm{N}$ fertilizer recommendation derived from these reflectance measurements. This algorithm used a sufficiency index (SI) calculated with measurements from both well-fertilized corn ("N-rich") and minimally fertilized corn ("Target"):

$$
\mathrm{SI}=\frac{\mathrm{VI}_{\text {Target }}}{\mathrm{VI}_{\mathrm{N}-\text { rich }}}
$$

where $\mathrm{SI}$ is the sufficiency index; $\mathrm{VI}_{\text {Target }}$ is the vegetative index obtained by averaging measurements from all plots that received $45 \mathrm{~kg} \mathrm{~N} \mathrm{ha}^{-1}$ at planting and where split fertilizer was to be applied, and $\mathrm{VI}_{\mathrm{N} \text {-Rich }}$ is the vegetative index obtained by averaging all plots of two high $\mathrm{N}$ treatments (225 and $270 \mathrm{~kg} \mathrm{~N} \mathrm{ha}^{-1}$ applied all at planting). The NDRE 
TA B L E 1 Methods associated with corn N recommendation tools included in this investigation. The tools include the farmer's nitrogen rate (NR), yield goal (YG), pre-plant nitrate test (PPNT), late spring nitrate test (LSNT 0/45), and pre-sidedress nitrate test (PSNT 0/45) with 0 or 45 kg $\mathrm{N} \mathrm{ha}^{-1}$ applied at-planting. Variables used in calculations include plant population (Pop), organic matter (OM), and cation exchange capacity (CEC)

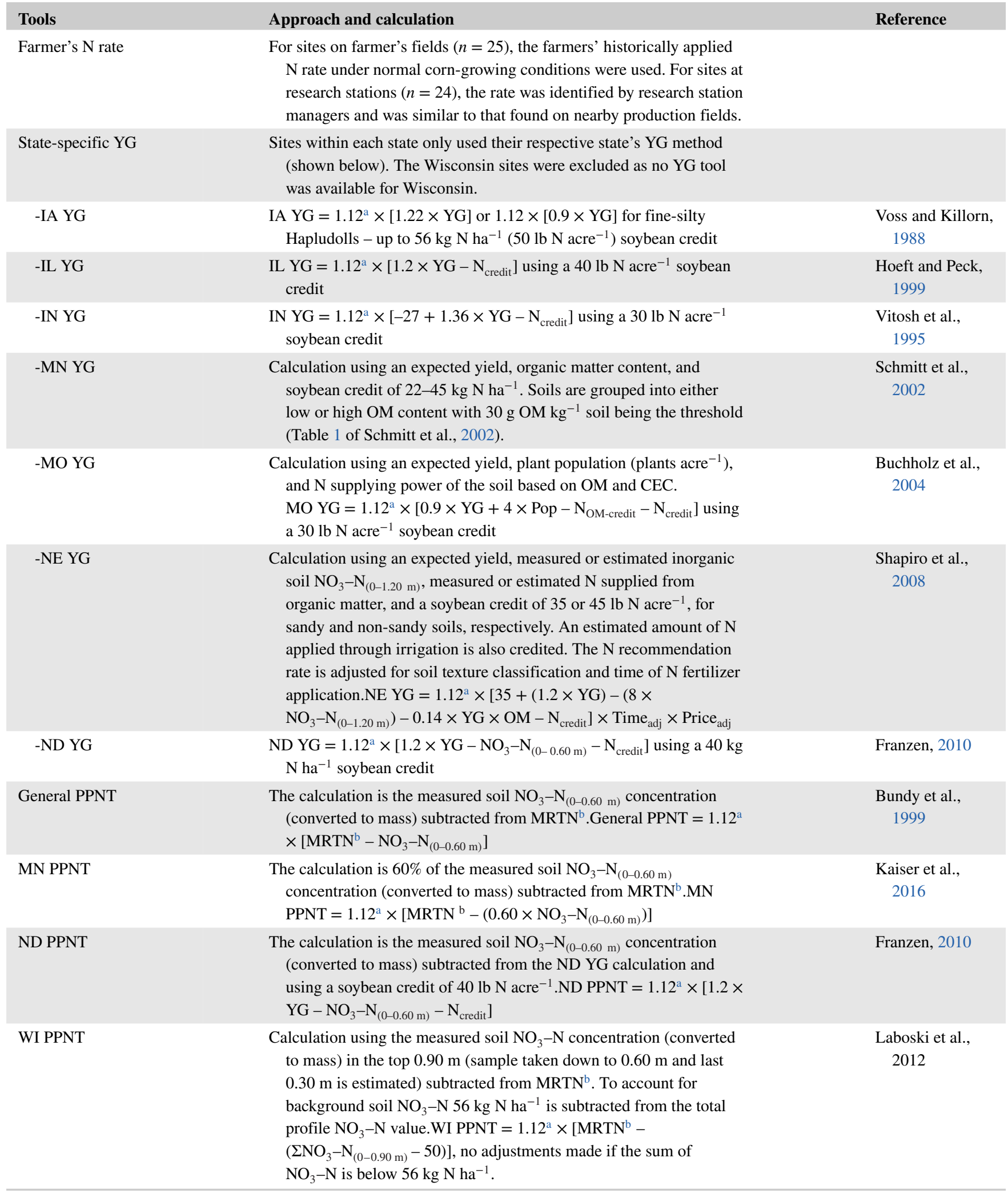


TA B L E 1 (Continued)

\begin{tabular}{|c|c|c|}
\hline Tools & Approach and calculation & Reference \\
\hline General PSNT & $\begin{array}{l}\text { MRTN or YG recommendation is adjusted proportionally based on if } \\
\text { soil } \mathrm{NO}_{3}-\mathrm{N}_{(0-0.30 \mathrm{~m})} \text { concentration is below } 25 \mathrm{mg} \mathrm{kg}^{-1} \text { and above } \\
10 \mathrm{mg} \mathrm{kg}{ }^{-1} \text {. The full recommended rate is applied if the soil } \\
\mathrm{NO}_{3}-\mathrm{N}_{(0-0.30 \mathrm{~m})} \text { concentration is below } 10 \mathrm{mg} \mathrm{kg}^{-1} \text { and no } \\
\text { additional } \mathrm{N} \text { is applied if above } 25 \mathrm{mg} \mathrm{kg}^{-1} \text {. }\end{array}$ & $\begin{array}{l}\text { Fernández et al., } \\
2009\end{array}$ \\
\hline LSNT & $\begin{array}{l}\text { Calculated using measured soil } \mathrm{NO}_{3}-\mathrm{N}_{(0-0.30 \mathrm{~m})} \text { concentration and a } \\
\text { critical limit of } 25 \mathrm{mg} \mathrm{kg}-1 \text {. To determine the } \mathrm{N} \text { recommendation } \\
\text { when } \mathrm{NO}_{3}-\mathrm{N}_{(0-0.30 \mathrm{~m})} \text { is below the critical threshold, the difference } \\
\text { between the critical threshold and the measured } \mathrm{NO}_{3}-\mathrm{N}_{(0-0.30 \mathrm{~m})} \\
\text { concentration is multiplied by } 8 \text {. The critical limit is reduced by } 3 \text { to } \\
5 \mathrm{mg} \mathrm{kg}^{-1} \text { when spring precipitation is } 20 \% \text { above normal.LSNT = } \\
1.12^{\mathrm{a}} \times\left[\left(25 \mathrm{mg} \mathrm{kg}^{-1}-\mathrm{NO}_{3}-\mathrm{N}_{(0-0.30 \mathrm{~m})} \mathrm{mg} \mathrm{kg}^{-1}\right) \times 8\right]\end{array}$ & $\begin{array}{l}\text { Sawyer and } \\
\text { Mallarino, } \\
2017\end{array}$ \\
\hline IN PSNT & $\begin{array}{l}\text { Calculation using yield goal and soil } \mathrm{NO}_{3}-\mathrm{N}_{(0-0.30 \mathrm{~m})} \text { concentration } \\
\text { (Table } 2 \text { of Brouder and Mengel, 2003). }\end{array}$ & $\begin{array}{l}\text { Brouder and } \\
\text { Mengel, } 2003\end{array}$ \\
\hline WI PSNT & $\begin{array}{l}\text { A soil } \mathrm{N} \text { credit is calculated based on soil } \mathrm{NO}_{3}-\mathrm{N}_{(0-0.30 \mathrm{~m})} \\
\text { concentration and on the yield potential of the soil. No N } \\
\text { application is recommended if the measured soil } \mathrm{NO}_{3}-\mathrm{N}_{(0-0.30 \mathrm{~m})} \\
\text { concentration is above } 21 \mathrm{mg} \mathrm{kg}^{-1} \text {. No } \mathrm{N} \text { credits are applied if the } \\
\text { soil } \mathrm{NO}_{3}-\mathrm{N}_{(0-0.30 \mathrm{~m})} \text { concentration is below } 10 \mathrm{mg} \mathrm{kg}^{-1} \text {. (Table } 6.6 \\
\text { of Laboski et al., 2012) }\end{array}$ & $\begin{array}{l}\text { Laboski et al., } \\
2012\end{array}$ \\
\hline MRTN & $\begin{array}{l}\text { Nitrogen rate response trials spanning multiple years. From each trial, } \\
\text { yield response is modeled as a function of } \mathrm{N} \text { fertilizer rate, and the } \\
\mathrm{N} \text { recommendation is determined by grouping trials and adjusting } \\
\text { for the price of corn and } \mathrm{N} \text {. Nitrogen recommendations are specific } \\
\text { for a geographical location or soil property. }\end{array}$ & $\begin{array}{l}\text { Sawyer et al., } \\
2006\end{array}$ \\
\hline $\begin{array}{l}\text { Canopy } \\
\text { reflectance } \\
\text { sensing }\end{array}$ & $\begin{array}{l}\text { Nitrogen recommendations are based on reflectance wavelengths } \\
\text { measured with proximal sensors. }\end{array}$ & $\begin{array}{l}\text { Holland and } \\
\text { Schepers, } \\
2010\end{array}$ \\
\hline
\end{tabular}

${ }^{\mathrm{a}} 1.12$ was used to convert $\mathrm{N}$ recommendations from $\mathrm{lb} \mathrm{N}$ acre ${ }^{-1}$ to $\mathrm{kg} \mathrm{N}^{-1}$.

${ }^{b}$ MRTN values were used unless states did not recommend MRTN, in which case that state's yield goal calculation was used.

vegetative index was calculated using the red-edge $(730 \mathrm{~nm}$; RE) and near-infrared (780 nm; NIR) wavelengths as shown:

$$
\mathrm{NDRE}=\frac{\mathrm{NIR}-\mathrm{RE}}{\mathrm{NIR}+\mathrm{RE}}
$$

Fertilizer $\mathrm{N}$ recommendations were then calculated:

$$
\begin{aligned}
\mathrm{N}_{\text {Rec }}= & \left(\mathrm{MZ}_{\mathrm{i}} \times \mathrm{N}_{\mathrm{Opt}}-\mathrm{N}_{\text {PreFert }}-\mathrm{N}_{\mathrm{CRD}}+\mathrm{N}_{\text {Comp }}\right) \\
& \times \sqrt{\frac{(1-\mathrm{SI})}{\Delta \mathrm{SI}}}
\end{aligned}
$$

where $\mathrm{N}_{\text {Rec }}$ is the calculated nitrogen fertilizer recommendation; $\mathrm{MZ}_{\mathrm{i}}$ is a scaling value $\left(0 \geq \mathrm{MZ}_{\mathrm{i}} \leq 2\right)$ used to adjust the nitrogen recommendation based on areas of high or low yield performance; $\mathrm{N}_{\mathrm{Opt}}$ the base nitrogen rate, which is determined by the farmer or researcher; $\mathrm{N}_{\text {PreFert }}$ is the amount of nitrogen already applied before sensing; $\mathrm{N}_{\mathrm{CRD}}$ is nitrogen credits associated with the previous crop, $\mathrm{NO}_{3}-\mathrm{N}$ in irrigation water, manure, or residual $\mathrm{NO}_{3}-\mathrm{N} ; \mathrm{N}_{\mathrm{Comp}}$ is an optional compensation factor for growth-limiting conditions; $\mathrm{SI}$ is the sufficiency index, and $\Delta S I$ is a value to define the response range. For this analysis, $\mathrm{MZ}_{\mathrm{i}}$ was left as the default value of $1.0, \mathrm{~N}_{\mathrm{opt}}$ was set as the recorded farmer or researcher's nitrogen rate for each site, and $\mathrm{N}_{\text {PreFert }}=45 \mathrm{~kg} \mathrm{~N} \mathrm{ha}^{-1}$. With no supportive information relative to $\mathrm{N}_{\mathrm{CRD}}$ and $\mathrm{N}_{\mathrm{Comp}}$, these two parameters were set to zero for all sites. The recommended value of 0.30 was used for $\Delta \mathrm{SI}$, which provides a response range between the measured vegetative index value between 0.70 and 1.00.

\section{8 | Incorporating soil and weather information into tools}

We used an ensemble learning method to incorporate soil and weather information into $\mathrm{N}$ recommendation tools as shown in Equations 4-6.

$$
\begin{gathered}
\sigma=\mathrm{EONR}_{\mathrm{Tool}}-\mathrm{EONR}_{\text {measured }} \\
\sigma=\mathrm{f} \text { (soil, weather) }
\end{gathered}
$$




$$
\mathrm{EONR}_{\text {ensemble }}=\mathrm{EONR}_{\mathrm{Tool}}-\hat{\sigma}
$$

The first step is to calculate the $\mathrm{N}$ recommendation tool's residual error $(\sigma)$ using Equation 4. The second step is to model $\sigma$ as a function of soil and weather measurements (Equation 5). The last step is to sum the tool's N recommendation and $\hat{\sigma}$ (Equation 6). For the second step, two algorithms were used. These included the elastic net regression (Zou \& Hastie, 2005) and a recursive partitioning decision tree (Loh, 2014). Using two algorithms allows for greater confidence in conclusions and provides unique methods for interpreting results.

Soil properties used in the models included measured physical and chemical soil properties. These were obtained from four soil cores collected down to $1.20 \mathrm{~m}$ from each of the sites (one from each block of treatments) and analyzing by pedological soil horizon for texture, bulk density, $\mathrm{pH}$ salt, $\mathrm{pH}$ water, cation exchange capacity (CEC), total $\mathrm{N}$, total $\mathrm{C}$, inorganic $\mathrm{C}$, organic $\mathrm{C}$, and organic matter as described in Table 2 . Soil properties were then depth weighted to obtain values for 0-to-0.30-, 0-to-0.60-, and 0-to-0.90-m depth increments and then averaged across all four profile samples.

Weather data were collected using on-site weather stations (HOBO U30 Automatic Weather Station; Onset Computer Corporation). Daily values were calculated for the maximum and minimum temperature and precipitation. These values were then used to engineer new features: total precipitation (PPT), growing degree days (GDD), corn heat units (CHU), Shanon diversity index (SDI) of precipitation (i.e., evenness of rainfall), and abundant and well-distributed rainfall (AWDR) (Tremblay et al., 2012). Weather measurement calculations were done for two time periods, $30 \mathrm{~d}$ before planting up to planting and from planting to the time of the split application (Table 2).

When two measurements were highly correlated $(|\mathrm{r}|>.85)$, the measurement with the largest mean absolute pair-wise correlation value was removed from the model (Table 3). This feature selection procedure was automated by using the findCorrelation function from the R 'caret' package (Kuhn, 2017). For the elastic net models, all features were normalized before running the model by subtracting the mean and dividing by the standard deviation for each explanatory variable. Normalization was necessary to minimize any bias the elastic net regression had with variables that comprised of different units or ranges of values (e.g., cumulative precipitation vs. bulk density). After finding the optimal hyperparameters (a parameter in the model that controls the learning process) all elastic net variable coefficients were "non-normalized" to their original scale to provide equations in relevant soil and weather units. For the decision tree modeling, normalizing features was not required.

The elastic net regressions and decision trees were fit with the 'caret', 'glmnet', and 'rpart' packages using R Statisti- cal Software (R Core Team, 2016; Friedman et al., 2010; Therneau \& Atkinson, 2019). The elastic net and decision tree models were optimized by tuning their hyperparameters (i.e., alpha and lambda parameters for elastic net regressions and a complexity parameter for decision trees) using a 10fold cross-validation repeated five times. Where each fold of the cross-validation the data was split randomly into 10-folds. Nine of the folds were selected as a training dataset to fit a model for each set of tuning parameters, and the 10th fold was used as the testing dataset to calculate the accuracy of the predicted model. This was repeated a total of 50 times and the accuracy for each combination of hyperparameters was determined using the average root mean square error (RMSE) across these 50-folds. The optimal model was selected based on the hyperparameters that produced the lowest RMSE value.

\section{9 | Metrics for evaluating performance improvement}

To adjust the $\mathrm{N}$ recommendation tools, the optimal models' predicted $\mathrm{N}$ rate values were subtracted from the original tool's $\mathrm{N}$ rate recommendation. Each adjusted tool's performance was tested based on the accuracy of predicting EONR. Models were ranked using a coefficient of determination $\left(r^{2}\right)$, RMSE, and the percentage of sites within \pm $30 \mathrm{~kg} \mathrm{~N} \mathrm{ha}{ }^{-1}$ of EONR [labeled as "reasonably close to EONR" (cEONR)]. The $r^{2}$ was calculated using a simple linear regression model based on the observed (measured EONR) and predicted (tool's unadjusted or adjusted $\mathrm{N}$ recommendations) values as:

$$
r^{2}=1-\frac{\sum_{i}\left(y_{i}-\hat{y}_{i}\right)^{2}}{\sum_{i}\left(y_{i}-\bar{y}\right)^{2}}
$$

where $y_{i}$ was the observed economically optimal nitrogen rate, $\hat{y}_{i}$ was the tool's unadjusted or adjusted nitrogen recommendation rates, and $\bar{y}$ was the mean of economically optimal nitrogen rate. The RMSE was calculated based on the difference between the adjusted tool's recommendation rates and EONR values as:

$$
\operatorname{RMSE}=\sqrt{\frac{1}{n} \sum_{i=1}^{n}\left(y_{i}-\hat{y}_{i}\right)^{2}}
$$

To scrutinize which algorithm provided the greatest overall tool improvement, linear slope coefficients from the unadjusted and adjusted tools were tested for differences. Slopes were determined using a linear regression model with EONR as a function of the unadjusted and adjusted tools based on the least-squares estimates and tested for significant differences using a pair-wise comparison from the 'emmeans' package in 
T A B L E 2 Weather and soil measurements used in the complete dataset with calculations, methods, and associated citations

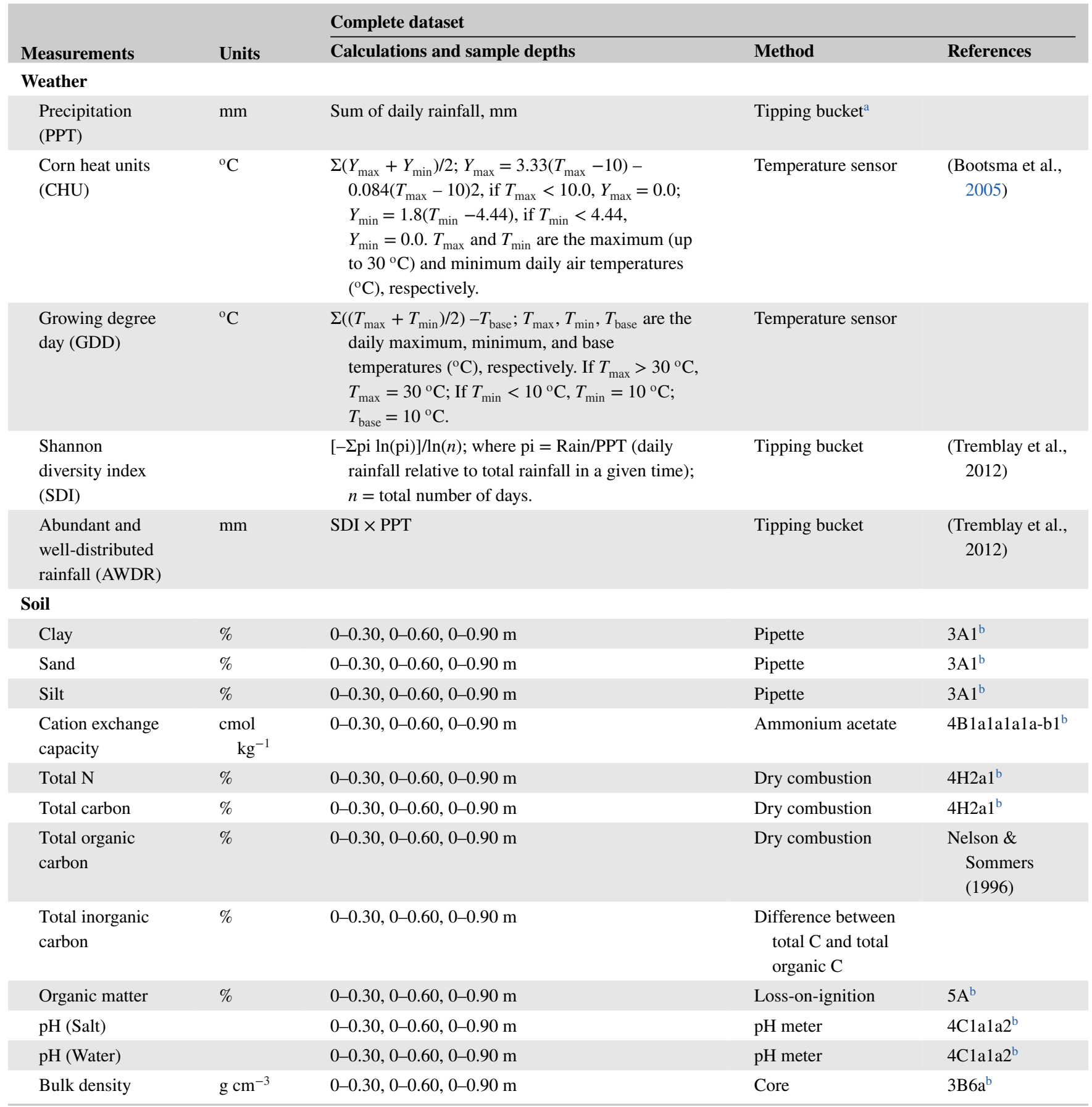

${ }^{a}$ Daily temperature and precipitation measured using $\mathrm{HOBO}$ weather station instrumentation (Onset Computer Corporation, Bourne, MA).

bIndicates the method code associated with the Kellogg Soil Survey Laboratory Methods Manual (Soil Survey Staff, 2014).

R (Lenth, 2018). The Tukey's Honest Significant Difference test was used to delineate significant differences between the slope coefficients $(\alpha=.05)$.

\section{3 | RESULTS AND DISCUSSION}

Using two unique algorithms (elastic net and decision tree) to modify $\mathrm{N}$ recommendation tools using soil and weather information helped improve most tools (Table 4, Figures 2 and 3). Across both algorithms, improvements ranged from no improvement to great improvement. The best improvements resulted in $r^{2}$ increases $\leq .48$ with the highest $r^{2}=.57$, RMSE decreases $\leq 38 \mathrm{~kg} \mathrm{~N}^{-1}$ with the lowest RMSE $=47 \mathrm{~kg} \mathrm{~N} \mathrm{ha}^{-1}$, and percentage of sites cEONR increases $\leq 29 \%$ with the highest value $=55 \%$. The input measurements identified to improve the prediction of EONR differed for each tool and algorithm. Findings for which soil and 
T A B L E 3 Weather and soil measurement inputs and associated range of values across all sites used as model inputs for the elastic net and decision tree algorithms after removing multicollinearity. Within the table, $\boldsymbol{V}$ indicates features selected to be used for ensemble learning and NA indicates not applicable

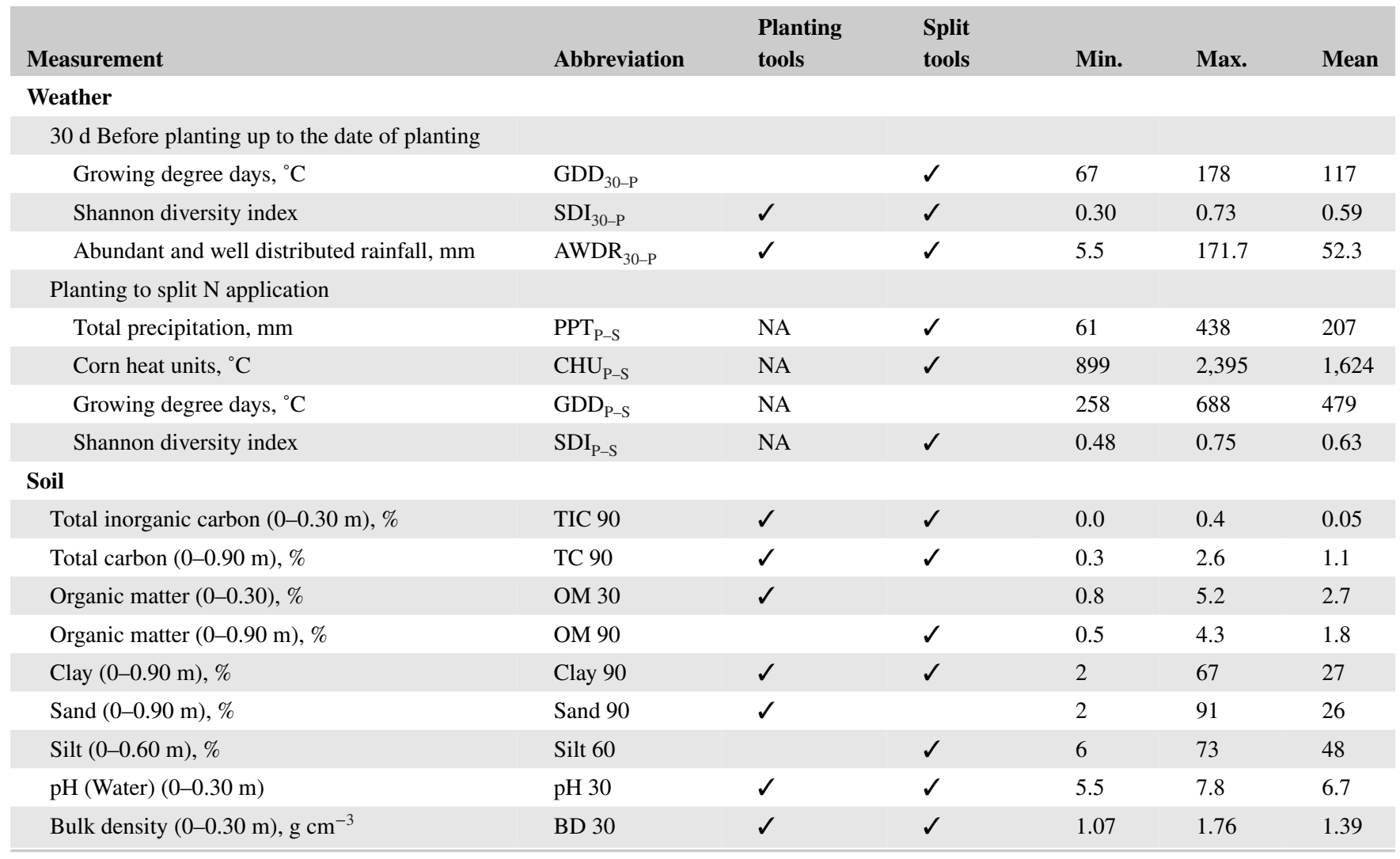

weather measurements were included for elastic net regression are in Table 5 (with normalized coefficients) and Table 6 (converted back to non-normalized coefficients after modeling). Findings for the decision tree method are summarized in Figures 4 and 5.

\section{1 | Elastic net outcomes}

For seven of the eight single $\mathrm{N}$ application tools, the elastic net identified several soil and weather measurements that helped improve the tools as identified by the performance metrics (i.e., $r^{2}$, RMSE, and cEONR). The improvement varied across tools and performance metrics. Compared to unadjusted, when averaging across these seven tools the $r^{2}$ values increased from .05 to .17 , the RMSE values decreased from 83 to $73 \mathrm{~kg} \mathrm{~N} \mathrm{ha}^{-1}$, and the cEONR values increased from 30 to $37 \%$ (Table 4). For these seven tools, the adjusted tools' median and the average difference between the tool's $\mathrm{N}$ recommendation and EONR came closer to 0 and the box-andwhisker's 95\% confidence intervals decreased (Figure 2). For General PPNT, the elastic net identified no soil and weather measurements to modify this tool. However, the intercept of the model showed improvement (i.e., RMSE and cEONR), with an increase of $\sim 40 \mathrm{~kg} \mathrm{~N} \mathrm{ha}^{-1}$ (Table 6). Five of these eight tools (i.e., Farmer NR, MRTN, Nebraska YG, Statespecific YG, and North Dakota PPNT) when unadjusted were not significant and not positively related to EONR $(\alpha=.05)$. After adjustment, all but the Nebraska YG became significant and positively related to EONR.

For 11 of the 13 split $\mathrm{N}$ application tools, the elastic net using soil and weather information helped improve tools' performance metrics. Compared to unadjusted, when averaging across these 11 tools, the $r^{2}$ values increased from .08 to .23 , the RMSE values decreased from 80 to $65 \mathrm{~kg} \mathrm{~N} \mathrm{ha}^{-1}$, and the cEONR values increased from 34 to $45 \%$ (Table 4). Adjusting these 11 tools with soil and weather information also showed improvements based on the median and average difference between each tool's $\mathrm{N}$ recommendation, EONR came closer to 0 , and the box-and-whisker's $95 \%$ confidence interval decreased (Figure 3). Unadjusted tools that were not significant and positively related to EONR (Farmer NR, MRTN, Nebraska YG, Indiana PSNT 0, General PSNT 45, and Wisconsin PSNT 45) became significant and positively related to EONR after adjustment.

The number of measurements used to adjust each tool ranged between 1 and 11 (Table 5). The most important and frequently used measurements to adjust single $\mathrm{N}$ application 
T A B L E 4 The performance of each N recommendation tool unadjusted and adjusted by soil and weather information as presented in Tables 5 and 6 (elastic net) and Figures 4 and 5 (decision tree). The precision and accuracy were evaluated using the coefficient of determination measured from a simple linear relationship between each tool and the economically optimal nitrogen rate (EONR), RMSE of the difference between a tool's N recommendation and EONR, and the percentage of sites within $\pm 30 \mathrm{~kg} \mathrm{~N} \mathrm{ha}^{-1}$ of EONR or "reasonably close to economically optimal nitrogen rate" (cEONR). The number of sites $(n)$ included in the evaluation differed for each tool based on the availability of information to test the tool. Tools include the State-specific yield goal (YG), pre-plant nitrate test (PPNT), pre-sidedress nitrate test (PSNT), and late-spring nitrate test (LSNT) with 0 and $45 \mathrm{~kg} \mathrm{~N} \mathrm{ha}^{-1}$ applied at-planting, maximum return to nitrogen (MRTN), and canopy reflectance sensing using the Holland and Schepers algorithm

\begin{tabular}{|c|c|c|c|c|c|c|c|c|c|c|}
\hline \multirow[b]{2}{*}{$\begin{array}{l}\text { N Fertilizer } \\
\text { recommendation tool }\end{array}$} & \multirow[b]{2}{*}{$n$} & \multicolumn{3}{|c|}{ Unadjusted tools } & \multicolumn{3}{|c|}{ Elastic net adjusted tools } & \multicolumn{3}{|c|}{ Decision tree adjusted tools } \\
\hline & & $\overline{r^{2}}$ & $\begin{array}{l}\text { RMSE } \\
\text { kg N } \\
\text { ha }^{-1}\end{array}$ & $\begin{array}{l}\text { cEONR } \\
\%\end{array}$ & $\overline{r^{2}}$ & $\begin{array}{l}\text { RMSE } \\
\text { kg N } \\
\text { ha }^{-1}\end{array}$ & $\begin{array}{l}\text { cEONR } \\
\%\end{array}$ & $\overline{r^{2}}$ & $\begin{array}{l}\text { RMSE } \\
\text { kg N } \\
\text { ha }^{-1}\end{array}$ & $\begin{array}{l}\text { cEONR } \\
\%\end{array}$ \\
\hline \multicolumn{11}{|l|}{ Single } \\
\hline Farmer NR & 49 & .01 & 88 & 31 & .20 & 73 & 41 & .49 & 58 & 47 \\
\hline State-specific YG & 43 & .04 & 84 & 23 & .09 & 77 & 33 & .37 & 64 & 37 \\
\hline General PPNT & 47 & .15 & 85 & 21 & .15 & 75 & 30 & .28 & 69 & 34 \\
\hline MN PPNT & 47 & .13 & 80 & 32 & .20 & 73 & 40 & .27 & 69 & 40 \\
\hline ND PPNT & 47 & .00 & 93 & 13 & .09 & 80 & 23 & .27 & 71 & 40 \\
\hline MRTN & 36 & .02 & 72 & 42 & .23 & 58 & 44 & .31 & 55 & 44 \\
\hline NE YG & 49 & .00 & 81 & 37 & .15 & 67 & 49 & .16 & 68 & 45 \\
\hline State-specific YG & 43 & .07 & 74 & 37 & .22 & 63 & 40 & .21 & 64 & 35 \\
\hline General PSNT 0 & 49 & .13 & 70 & 43 & .13 & 70 & 41 & .24 & 64 & 39 \\
\hline LSNT 0 & 49 & .24 & 68 & 37 & .39 & 56 & 55 & .36 & 58 & 47 \\
\hline IN PSNT 0 & 49 & .03 & 83 & 24 & .21 & 64 & 47 & .18 & 67 & 45 \\
\hline WI PSNT 0 & 49 & .11 & 73 & 41 & .11 & 73 & 39 & .21 & 66 & 37 \\
\hline General PSNT 45 & 49 & .07 & 92 & 29 & .15 & 74 & 43 & .38 & 60 & 47 \\
\hline LSNT 45 & 49 & .14 & 79 & 43 & .27 & 65 & 35 & .14 & 72 & 31 \\
\hline
\end{tabular}

tools were the $\mathrm{GDD}_{30-\mathrm{P}}, \mathrm{AWDR}_{30-\mathrm{P}}$, soil organic matter $(\mathrm{OM})(0-0.30 \mathrm{~m})$, and total carbon (TC) $(0-0.90 \mathrm{~m})$. Whereas the most important and frequently used measurements for split tools were the $\mathrm{SDI}_{\mathrm{P}-\mathrm{S}}$, soil $\mathrm{pH}(0-0.30 \mathrm{~m})$, and TC $(0-0.90 \mathrm{~m})$. When looking across both single and split $\mathrm{N}$ application tools, the $\mathrm{SDI}_{30-\mathrm{P}}$ and bulk density $(0-0.30 \mathrm{~m})$ were influential about $50 \%$ of the time.

For weather measurements, $\mathrm{GDD}_{30-\mathrm{P}}$ was sometimes helpful (for both single and split tools), but it is not surprising that the most influential information used to adjust tools were precipitation-based measurements (Table 5). Precipitation drives soil organic matter mineralization, yield potential, $\mathrm{NO}_{3}-\mathrm{N}$ leaching losses, and $\mathrm{N}$ uptake (Cassman \& Munns, 1980; Melkonian et al., 2007; Schröder et al., 2000; Wilhelm
$\&$ Wortmann, 2004). Precipitation-based measurements often have a bigger impact on $\mathrm{N}$ fertilizer response and EONR predictions than soil parameters (Sela et al., 2017; Sogbedji et al., 2001; Tremblay et al., 2012). For all the precipitation basedmeasurements in this analysis, we found only the $\mathrm{SDI}_{\mathrm{P}-\mathrm{S}}$ to have a significant and positive linear relationship with EONR $\left(r^{2}=.22\right.$ for split application EONR). In all cases, increasing $\mathrm{SDI}_{\mathrm{P}-\mathrm{S}}$ values increased the adjusted tools' $\mathrm{N}$ rate recommendations (Table 6). The magnitude of the $\mathrm{SDI}_{\mathrm{P}-\mathrm{S}}$ adjustment differed by tool, ranging from +59 to $+241 \mathrm{~kg} \mathrm{~N} \mathrm{ha}^{-1}$. For reference, an SDI value of 1.0 indicates equal precipitation amounts that were evenly spaced among the measurement timeframes. An SDI of 0 indicates all precipitation occurred on a single day. 
ఫ

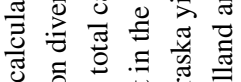

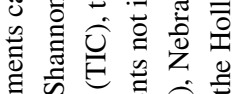

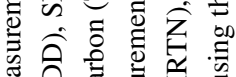

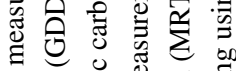
ह 那

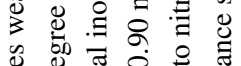
密

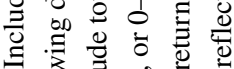

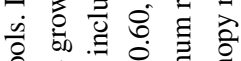
o 0 方

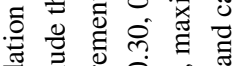

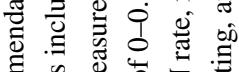

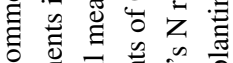

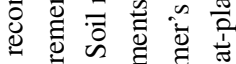
Z声宁总焉

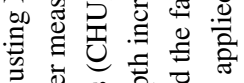

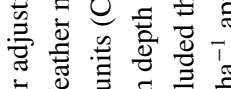
s.

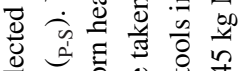

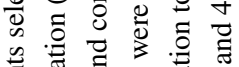
1)

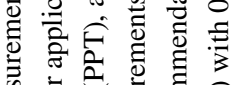
䓌

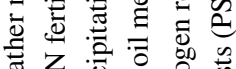
Ð

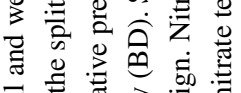

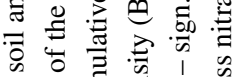

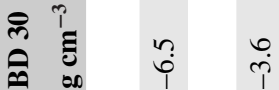

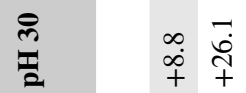

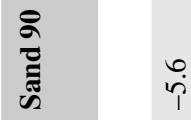

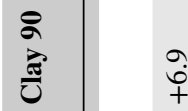

$\stackrel{8}{=}$

竞

实

हై

ร

ะ

లి

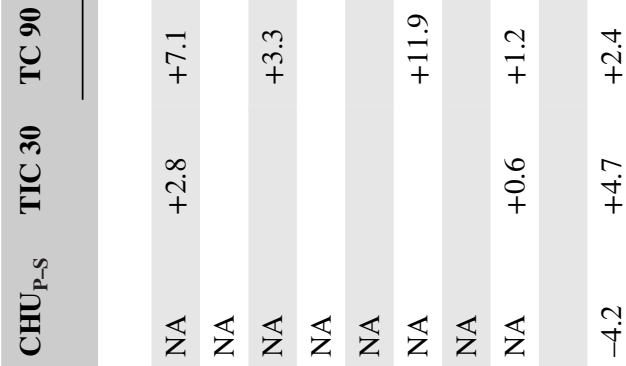

के

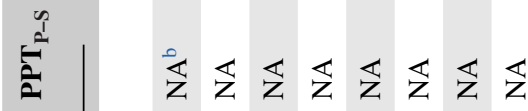

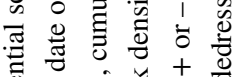
Ð

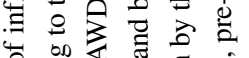

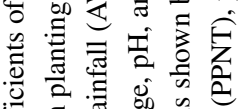

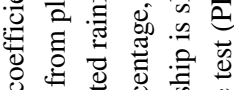

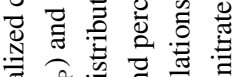

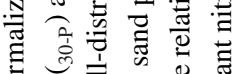
ప્ర

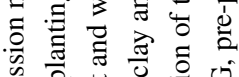
के ट⿱

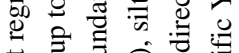

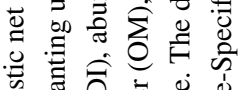

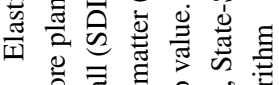
n

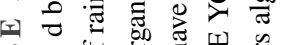
ज «

定

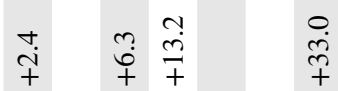

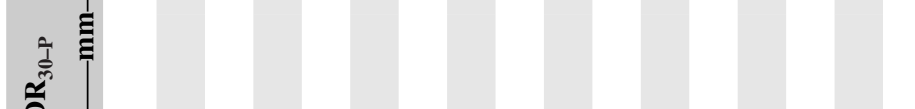

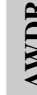

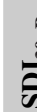

:

$\stackrel{1}{T}$ in

के iे

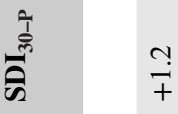

ก



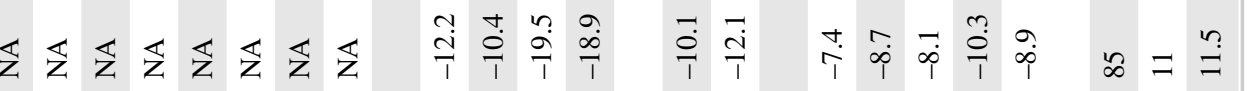

$\ddot{\varphi}$

$\stackrel{\circ}{\circ}+$

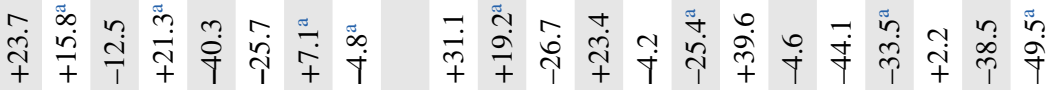

$\stackrel{+}{+} \underset{i}{4}$

$\stackrel{n}{+} a+i$

$\stackrel{m}{+}$ m

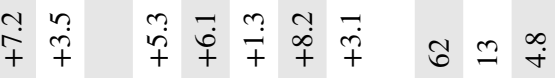<smiles>c1ccc2ccccc2c1</smiles> 
T A B L E 6 Elastic net regression non-normalized coefficients of weather and soil parameters used to adjust N recommendation tools. Tools include the farmer's N rate, maximum return to nitrogen (MRTN), yield goal (YG), pre-plant nitrate test (PPNT), pre-sidedress nitrate test (PSNT) and late spring nitrate test (LSNT) with 0 and $45 \mathrm{~kg} \mathrm{~N} \mathrm{ha}^{-1}$ applied at-planting, and canopy reflectance sensing using the Holland and Schepers algorithm. Includes weather measurements calculated from $30 \mathrm{~d}$ before planting up to planting ( ${ }_{30-\mathrm{P}}$ ) and from planting to the date of the split $\mathrm{N}$ fertilizer application ( $\left.\mathrm{P}_{\mathrm{S}}\right)$. Weather measurements include the growing degree days (GDD; $\left.{ }^{\circ} \mathrm{C}\right)$, Shannon diversity index of rainfall (SDI), and abundant and well-distributed rainfall (AWDR; mm), cumulative precipitation (PPT; mm), and corn heat units (CHU; $\left.{ }^{\circ} \mathrm{C}\right)$. Soil measurements include sand, silt, and clay (\%), total carbon (TC; \%), total inorganic carbon (TIC; \%), organic matter (OM; \%), pH, and bulk density (BD; $\mathrm{g} \mathrm{cm}^{-3}$ )

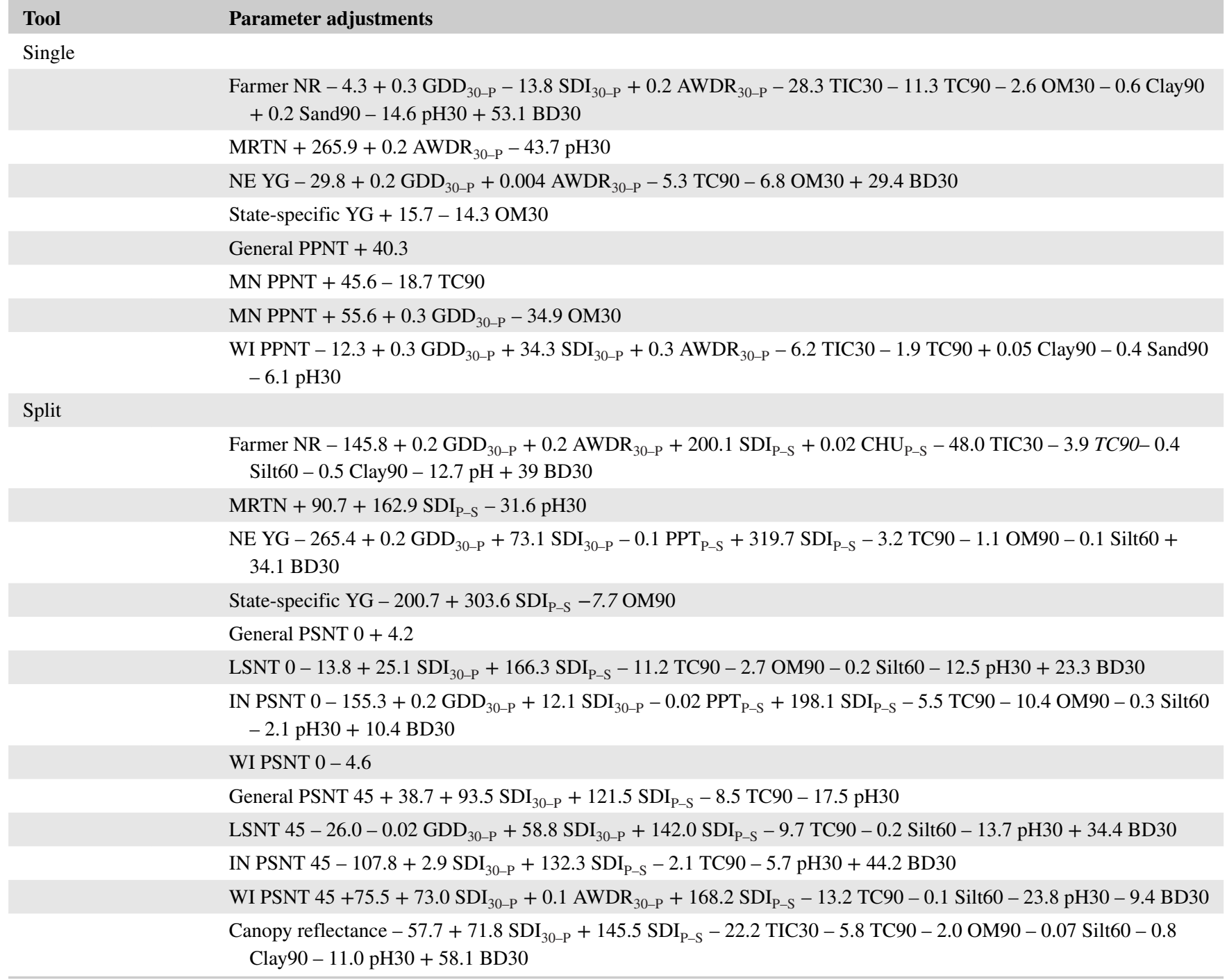

We postulate $\mathrm{SDI}_{\mathrm{P}-\mathrm{S}}$ helped increase $\mathrm{N}$ recommendations because this measurement could be a good predictor of increased $\mathrm{N}$ loss at high $\mathrm{SDI}_{\mathrm{P}-\mathrm{S}}$ values. Nitrogen loss (i.e., soil surface runoff, $\mathrm{N}$ leaching, or denitrification) increases when soil moisture content is high, and thus more $\mathrm{N}$ would be required to compensate for the loss (Maag \& Vinther, 1996). Maintained high soil moisture is more likely to occur when precipitation events are evenly spaced (high SDI) and total precipitation is high. On the other hand, infrequent precipitation (Low $\mathrm{SDI}_{\mathrm{P}-\mathrm{S}}$ values) corresponded with lower EONR values. The lower fertilizer $\mathrm{N}$ need could have resulted from deeper rooting systems that are often promoted when soils are dry during early vegetative growth stages (Nielsen, 2013). A deep rooting system would increase a plant's access to profile nitrate resulting in less fertilizer need. It is difficult to surmise how SDI values affects $\mathrm{N}$ response, as SDI values can be calculated equifinality (i.e., $10 \mathrm{~mm}$ of precipitation everyday results in the same SDI value as $1 \mathrm{~mm}$ of precipitation everyday) and therefore masks the magnitudinal effect of precipitation. But compared to $\mathrm{SDI}_{\mathrm{P}-\mathrm{S}}$, including the magnitude effect (i.e., AWDR) showed no improved predictability of EONR or the difference between tools' $\mathrm{N}$ recommendation and EONR.

The most frequently appearing soil measurement in the elastic net models were $\mathrm{pH}(0-0.30 \mathrm{~m})$ and TC $(0-0.90 \mathrm{~m})$ (Table 5). As pH or TC increased the adjusted tools' $\mathrm{N}$ recommendations decreased (Table 6). Soil $\mathrm{pH}$ resulted in 


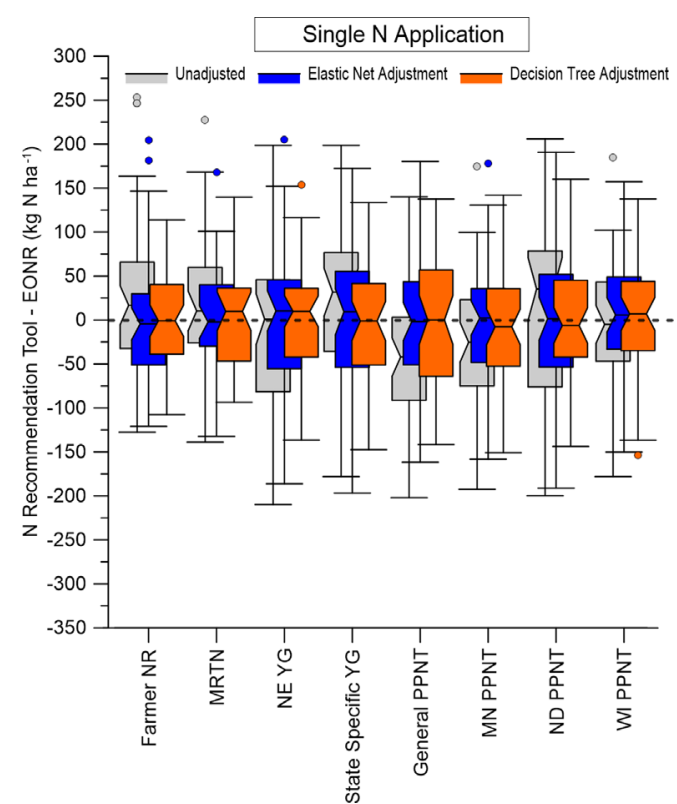

F I G U R E 2 Box-and-whisker plots showing the difference between each of the single application (at-planting) tools' $\mathrm{N}$ recommendation and the economically optimal nitrogen rate (EONR) for tools before and after adjusting with soil and weather information. The median is reported by the value in the middle of the box. Notches on the side of each box represent the $95 \%$ confidence interval around the median. Limits of the box indicate the first and third quartile, whiskers represent $1.5 \times$ interquartile range, and small circles are outliers. Improvement is assessed by the decrease in the box-and-whisker length, and the box is centered on the zero line (dashed line)

tools being adjusted between -11 and $-343 \mathrm{~kg} \mathrm{~N} \mathrm{ha}^{-1}$. The TC 90 resulted in tools being adjusted between -1 and $-49 \mathrm{~kg} \mathrm{~N} \mathrm{ha}^{-1}$ (Table 6).

Soil $\mathrm{pH}$ affects soil fertility and drives many factors of the $\mathrm{N}$ cycle. For example, the microbial-driven conversion of ammonium to nitrate is optimized at $\mathrm{pH}$ values above 7.5 (Kyveryga et al., 2004) and denitrification rates are greatest at pH values $<7$ (Šimek \& Cooper, 2002). Soil pH was shown to be an important factor influencing corn yield and protein levels in two Illinois corn fields (Miao et al., 2006). However, directly relating $\mathrm{pH}$ to EONR in our study showed no significant relationship ( $P$ values of .18 and .14 for single and split EONR, respectively). Northern sites tended to have higher $\mathrm{pH}$ values because these soils were formed under drier and colder conditions (Figure 1b; e.g., North Dakota), and therefore were less weathered with free calcium carbonate or a recent lime application was used to raise the $\mathrm{pH}$ (measured total inorganic carbon (TIC) in the top $0.30 \mathrm{~m}$ only occurred in Illinois, Missouri, North Dakota, Minnesota, and Wisconsin sites and ranged from 0.01 to $0.42 \%$; with North Dakota and Minnesota having the highest values). Decreasing any of the tools' recommendations based on higher soil $\mathrm{pH}$ was helpful for many of the northern sites such as North Dakota $(\mathrm{pH}$ ranged

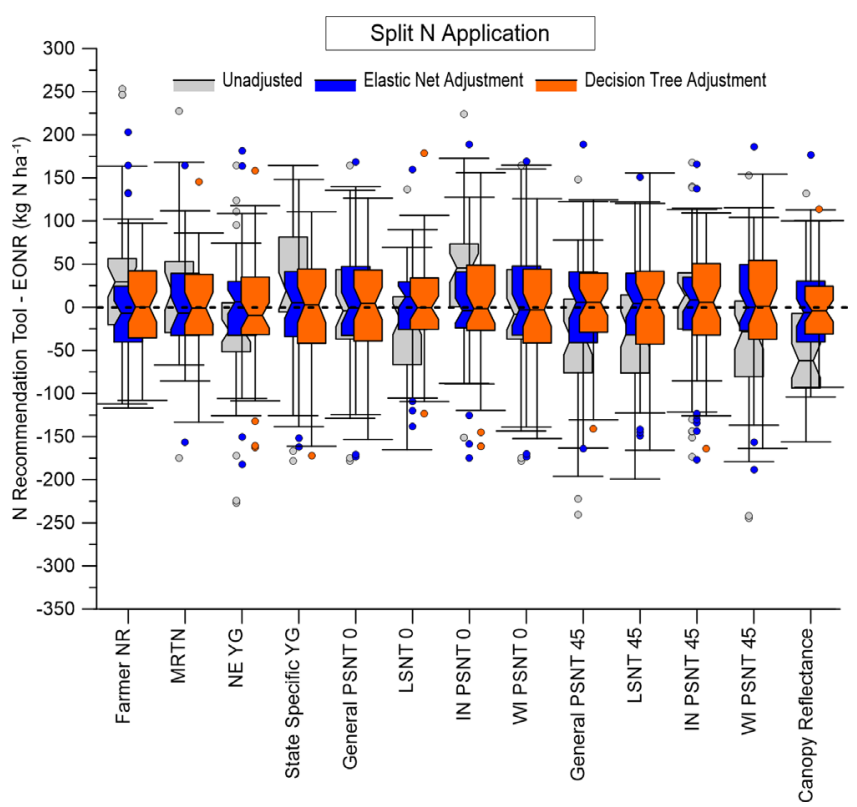

F I G U R E 3 Box-and-whisker plots showing the difference between each of the split application (at-planting + sidedress) tools' $\mathrm{N}$ recommendation and the economically optimal nitrogen rate (EONR) for tools before and after adjusting with soil and weather information. The median is reported by the value in the middle of the box. Notches on the side of each box represent the $95 \%$ confidence interval around the median. Limits of the box indicate the first and third quartile, whiskers represent $1.5 \times$ interquartile range, and small circles are outliers. Improvement is assessed by the decrease in the box-and-whisker length, and the box is centered on the zero line (dashed line)

between 6.7 and 7.8) and Wisconsin ( $\mathrm{pH}$ ranged between 6.1 and 7.5), where a few of these sites were non-responsive to $\mathrm{N}$ fertilizer.

Total $\mathrm{C}(0-0.90 \mathrm{~m})$ was meaningful for adjusting 13 of the 21 tools (Table 5). The TC 90 accounted for $16 \%(P$ value $=.004)$ and $13 \%(P$ value $=.01)$ of the variability around the single and split EONRs, respectively. The TC values were related to organic $\mathrm{C}$-when averaged across all sites, organic $\mathrm{C}$ accounted for $88 \%$ of the TC 90 . The northern sites contained the highest TC 90 content (and highest organic $\mathrm{C}$ content) and were co-located with sites with high $\mathrm{pH}$ values. Adjusting for organic $\mathrm{C}$ could account for mineralization rates, as positive linear and quadratic responses $\left(r^{2}>.24\right)$ were observed using this data with a $28 \mathrm{~d}$ anaerobic potentially mineralizable $\mathrm{N}$ soil test (Clark et al., 2019). Higher mineralization rates would help explain the lack of fertilizer $\mathrm{N}$ response for many of the northern locations. In colder climates and with shorter growing seasons these soils accumulated more organic matter than soils in warmer wetter regions, and thus a potentially greater soil $\mathrm{N}$ supply exists in these soils today (Figure 1b). Accounting for mineralization indirectly through TC allows tools to account for $\mathrm{N}$ supplied by the soil. The inability for tools to account for 


\section{Single N Application}

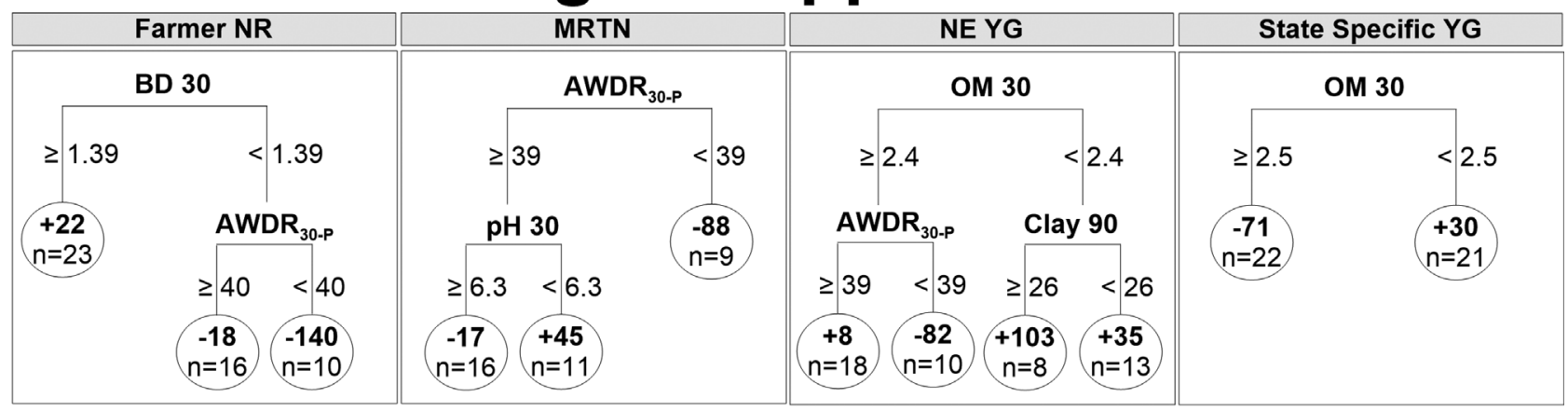

\begin{tabular}{|c|c|c|c|c|c|c|c|}
\hline \multicolumn{2}{|c|}{ General PPNT } & \multicolumn{2}{|c|}{ MN PPNT } & \multicolumn{2}{|c|}{ ND PPNT } & \multicolumn{2}{|c|}{ WI PPNT } \\
\hline \multicolumn{2}{|c|}{ AWDR $_{30-P}$} & \multicolumn{2}{|c|}{ TC 90} & \multicolumn{2}{|c|}{ OM 30} & \multicolumn{2}{|c|}{ AWDR $_{30-p}$} \\
\hline$\geq 38$ & $<38$ & $\geq 1.5$ & $<1.5$ & $\geq 2.4$ & $<2.4$ & $\geq 38$ & $<38$ \\
\hline$n=32$ & $n=15$ & $n=10$ & $n=37$ & $n=27$ & $n=20$ & $n=32$ & $n=12$ \\
\hline
\end{tabular}

F I G U R E 4 Decision trees models used to adjust single application (at-planting) N recommendation tools with soil and weather measurements. The weather measurement used was the abundant and well-distributed rainfall calculated from $30 \mathrm{~d}$ before planting up to planting (AWDR ${ }_{30-\mathrm{P}}$; mm). Soil measurements were taken in depth increments of $0-0.30,0-0.60$, or $0-0.90 \mathrm{~m}$. Soil measurements and their respective depth include total carbon (TC 90; $\mathrm{g} \mathrm{kg}^{-1}$ ), organic matter (OM 30; $\mathrm{g} \mathrm{kg}^{-1}$ ), clay (Clay 90; $\mathrm{g} \mathrm{kg}^{-1}$ ), $\mathrm{pH}(\mathrm{pH} 30)$, and bulk density (BD 30; $\mathrm{g} \mathrm{cm}^{-3}$ ). Nitrogen recommendation tools include the farmer's $\mathrm{N}$ rate, maximum return to nitrogen (MRTN), Nebraska yield goal (NE YG), State-specific YG, and four different pre-plant nitrate tests (PPNT). The adjustment recommended for each tool in $\mathrm{kg} \mathrm{N} \mathrm{ha}^{-1}$ and the number of observations used in each split are circled at the end of each terminal node

$\mathrm{N}$ mineralization rates is one reason that they performed poorly across a wide geographical region, as shown in Ransom et al. (2020).

\section{2 | Decision tree outcomes}

For all eight single $\mathrm{N}$ application tools, decision trees identified at least one measurement that helped improve these tools. Going from unadjusted to adjusted, and averaging across these eight tools, the $r^{2}$ values increased from .05 to .35 , the RMSE values decreased from 83 to $64 \mathrm{~kg} \mathrm{~N} \mathrm{ha}^{-1}$, and the cEONR values increased from 30 to $38 \%$ (Table 4). However, the adjustments to the MRTN and Nebraska YG recommendations negatively affected the cEONR values as a few sites were moved further away from EONR than those that were adjusted cEONR. Overall, the modifications resulted in the average and median difference between each tool's $\mathrm{N}$ recommendation and EONR coming closer to 0, and all box-and-whisker's 95\% confidence intervals decreasing (Figure 2). These adjustments resulted in all tools being significant and positively related to EONR.
For 12 of the 13 split tools, decision trees identified at least one measurement that helped improve these tools (with no improvement to LSNT 45). Compared to the unadjusted, when averaging across these 12 tools, the $r^{2}$ values increased from .08 to .30 , the RMSE values decreased from 79 to $61 \mathrm{~kg} \mathrm{~N} \mathrm{ha}^{-1}$, and the cEONR values increased from 35 to $41 \%$ (Table 4). As with the other adjusted tools, the average difference between each tool's $\mathrm{N}$ recommendation and EONR was nearer to 0 and the box-and-whisker's $95 \%$ confidence interval decreased (Figure 3). Across all 12 tools, six were not significant and positively related to EONR when unadjusted (Farmer NR, MRTN, Nebraska YG, Indiana PSNT 0, General PSNT 45, and Wisconsin PSNT 45), but they all became significant and positively related to EONR after adjustment.

The decision tree models resulted in one, two, or three splits as shown in Figures 4 and 5. For each of the important soil and weather measurements, the values used to create a split were similar across all tools. The most frequently used measurements to adjust single $\mathrm{N}$ application tools included the $\mathrm{AWDR}_{30-\mathrm{P}}$ (Figure 4), while for split tools it was the $\mathrm{AWDR}_{30-\mathrm{P}}$ and bulk density $(0-0.30 \mathrm{~m})$ measurements (Figure 5). The $\mathrm{AWDR}_{30-\mathrm{P}}$ was important for 10 of the 21 
Split N Application

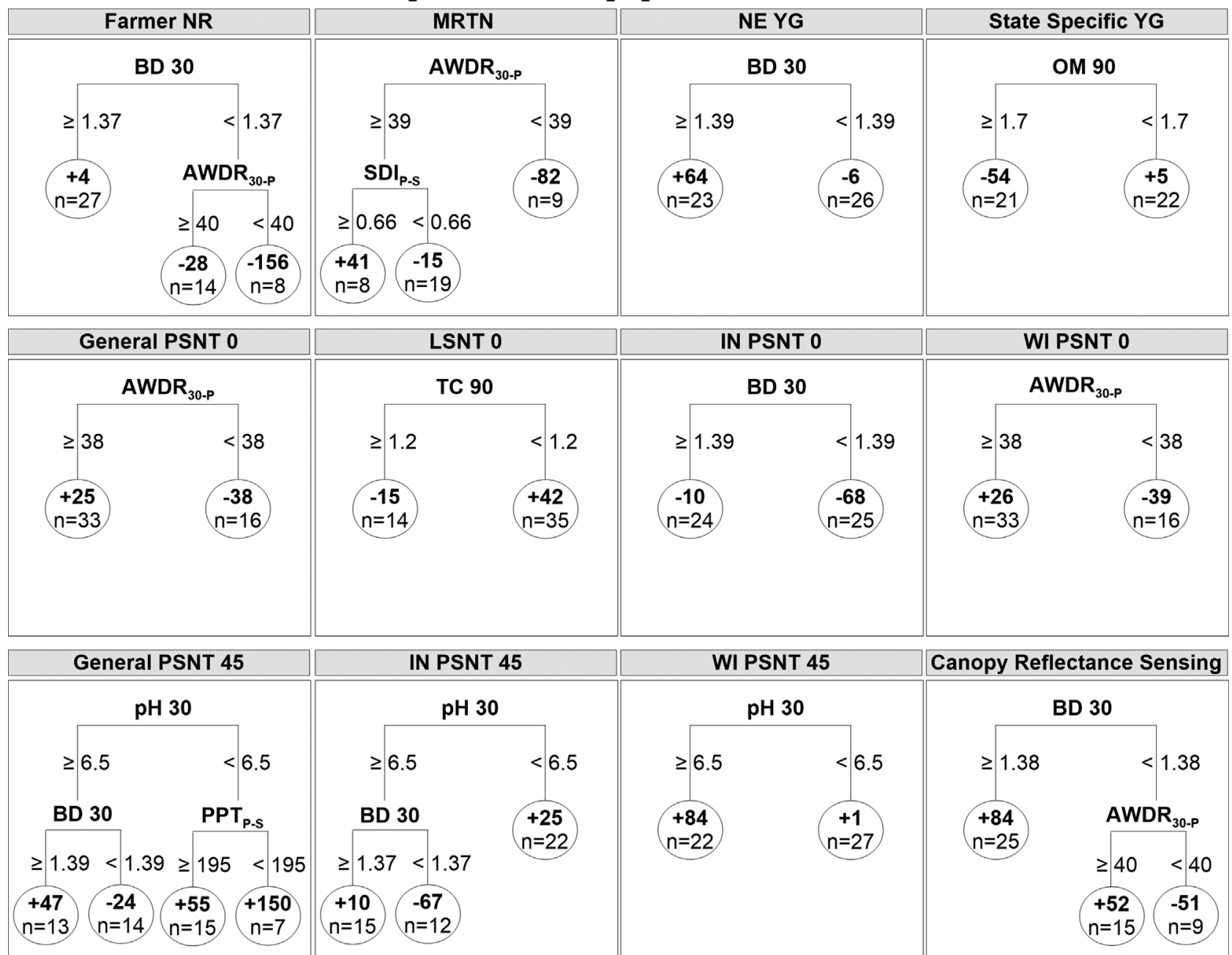

F I G U R E 5 Decision trees models used to adjust split application (at-planting + sidedress) N recommendation tools with soil and weather measurements. Weather measurements were calculated from $30 \mathrm{~d}$ before planting up to planting $\left(_{30-\mathrm{P}}\right)$ and from planting to the date of the split $\mathrm{N}$ fertilizer application $\left(_{\mathrm{P}-\mathrm{S}}\right)$. Weather measurements include the cumulative precipitation $\left(\mathrm{PPT}_{\mathrm{P}-\mathrm{S}} ; \mathrm{mm}\right)$, Shannon diversity index of rainfall $\left(\mathrm{SDI}_{\mathrm{P}-\mathrm{S} \text {; }}\right.$ unitless), and abundant and well-distributed rainfall $\left(\mathrm{AWDR}_{30-\mathrm{P}} ; \mathrm{mm}\right)$. Soil measurements were taken in depth increments of 0-0.30, 0-0.60, or 0-0.90 m. Soil measurements and their respective depth include total carbon (TC 90; $\mathrm{g} \mathrm{kg}^{-1}$ ), organic matter (OM 90; $\left.\mathrm{g} \mathrm{kg}^{-1}\right)$, $\mathrm{pH}(\mathrm{pH} 30)$, and bulk density (BD 30; $\mathrm{g} \mathrm{cm}^{-3}$ ). Nitrogen recommendation tools included the farmer's $\mathrm{N}$ rate, maximum return to nitrogen (MRTN), Nebraska yield goal (NE YG), State-specific YG, pre-sidedress nitrate tests (PSNT) with 0 and $45 \mathrm{~kg} \mathrm{~N} \mathrm{ha}^{-1}$ applied at-planting, and canopy reflectance sensing using the Holland and Schepers algorithm. The late spring nitrate test with $45 \mathrm{~kg} \mathrm{~N} \mathrm{ha}^{-1}$ applied at-planting (LSNT 45) was not included because the decision tree found no splits. The adjustment recommended for each tool in $\mathrm{kg} \mathrm{N} \mathrm{ha}^{-1}$ and the number of observations used in each split are circled at the end of each terminal node

decision tree adjustments. Across all decision trees adjustments, the AWDR ${ }_{30-P}$ splits occurred between 38 and $40 \mathrm{~mm}$. For reference, all sites with $\mathrm{AWDR}_{30-\mathrm{P}}<40 \mathrm{~mm}$ received $\leq 66 \mathrm{~mm}$ of precipitation and had $\mathrm{SDI}_{30-\mathrm{P}}$ values between 0.30 (i.e., most precipitation occurring close together) and 0.65 (i.e., adequately distributed precipitation). Agronomically it is unclear why $\mathrm{AWDR}_{30-\mathrm{P}}$ (a measurement of abundant and well-distributed precipitation) would be so influential at adjusting a wide variety of single and split $\mathrm{N}$ application tools. Precipitation before planting could affect planting conditions, seed germination, and impact soil profile water content which subsequently could affect leaching or denitrification losses. But presumably pre-plant precipitation would have little impact on season-long $\mathrm{N}$ dynamics or grain production since no $\mathrm{N}$ fertilizer was applied during this period. Regardless of the agronomic reasons, for this set of 49 site-years, this measurement helped in many tool adjustments by identifying $\mathrm{N}$ need based on low and high $\mathrm{AWDR}_{30-\mathrm{P}}$ values. For example, tool recommendations tended to overestimate EONR for sites with low $\mathrm{AWDR}_{30-\mathrm{P}}$ values but adjusting tools for $\mathrm{AWDR}_{30-\mathrm{P}}$ helped correct for this. 
Also, bulk density (BD) (0-0.30 m) was an important measurement for adjusting tools. This measurement helped adjust 7 of the 21 tools. Across all tools, the BD split occurred at values between 1.37 and 1.39. For $\mathrm{BD}$ values $<1.37 \mathrm{rec}-$ ommendations were generally adjusted down, and for values $\geq 1.37$ recommendation were adjusted up. High BDs reduce root elongation and inhibit water and nutrient uptake (Passioura, 1991). Often soil compaction contributes to higher $\mathrm{BD}$, and can limit water movement which can cause higher denitrification rates (Gregorich et al., 2014). Bulk density was found to have a negative relationship with potentially mineralizable $\mathrm{N}$-indicating that sites with high BDs had reduced soil N supply (Clark et al., 2019). This relates well with observations of higher $\mathrm{N}$ needed at sites with high BD.

\section{3 | Which tools were best adjusted?}

To facilitate a discussion about which tools were best adjusted, we grouped tools into three categories of tool improvement ("most improved", "moderately improved", and "least improved"). The classification was based on how well the average of both algorithms improved the tools across all three metrics of performance. A threshold for each metric was chosen to separate the 21 tools into the three groups. The thresholds were an increased $r^{2}$ value of .15 , a decreased RMSE of $13 \mathrm{~kg} \mathrm{~N} \mathrm{ha}^{-1}$, and an increased percentage of site cEONR of $10 \%$. For "most improved" tools, the average of the elastic net and decision tree's metrics all had to be greater than these values. For "least improved" tools, the average metrics all had to equal or be less than these values. Tools that did not fit in either of these categories-because at least one of the average metrics was above the thresholds, while the other metric(s) were below the thresholds-were classified as "moderately improved".

Most improved tools are presented in Figure 6. Unadjusted, these tools had poor performance metrics and therefore had the most room for improvement. For example, all unadjusted tools in the "most improved" category had $r^{2}$ between .00 and .13 , RMSE between 83 and $93 \mathrm{~kg} \mathrm{~N}^{-1}$, cEONR between 13 and $31 \%$, and five of the seven unadjusted tools were not significantly related to EONR. For "most improved" tools, incorporating soil and weather information improved the tools' performance by decreasing $\mathrm{N}$ recommendations when EONR values were low, while also increasing $\mathrm{N}$ recommendations when EONR values were high. These adjustments helped $\mathrm{N}$ recommendations to better align with EONR as seen by points aligning closer to the 1:1 line in Figure 6.

Moderately improved tools are shown in Figure 7. For these tools, using soil and weather information improved the tools but not for all performance metrics. The reason for this was that the unadjusted "moderately improved" tools were already performing better than unadjusted "most improved" tools. The unadjusted "moderately improved" tools had a $r^{2}$ between .00 and .24 , RMSE between 68 and $90 \mathrm{~kg} \mathrm{~N} \mathrm{ha}^{-1}$, cEONR between 21 and $42 \%$, and four of the seven unadjusted tools were not significantly related to EONR. Like the "most improved" performing tools, the "moderately improved" tools were adjusted in similar ways. Tools that could not account for sites with low or high EONR values were shifted.

Least improved tools are illustrated in Figure 8. There was minimal improvement for some of these tools as they were some of the better performing tools without adjustment. Before adjustment they had $r^{2}$ between .07 and .16, RMSE between 70 and $80 \mathrm{~kg} \mathrm{~N} \mathrm{ha}^{-1}$, cEONR between 32 and $43 \%$, and all were significantly related to EONR. Of these seven tools, four showed minimal improvement (Minnesota PPNT, Wisconsin PPNT, State-specific YG, and Indiana PSNT 45), showing that soil and weather information was helpful for adjusting a few sites but did not provide meaningful improvement for all sites. For the other three tools, no soil or weather adjustments helped. Therefore, only a constant value was used to adjust these tools, which resulted in a minimal improvement (Table 4).

\subsection{Comparing model methods}

The elastic net algorithm performs well when the number of observations is high and modeling includes interactions and nonlinearities when interactions and nonlinearities are present (Grömping, 2009). For this analysis the number of observations was relatively low and modeling excluded interactions or second order polynomials because previous research showed minimal improvements with such an analysis (Ransom et al., 2019). Decision trees can work well with minimal observations and can model data where interactions and nonlinearities are present (Grömping, 2009). With this analysis, decision tree modeling gave the greatest improvement. The decision tree outperformed the elastic net with increased $r^{2}$ values of .18 and .07 and decreased RMSE values of 9 and $4 \mathrm{~kg} \mathrm{~N} \mathrm{ha}^{-1}$ for single and split $\mathrm{N}$ application tools, respectively (Table 4). The decision tree best adjusted sites with extremely low and high $\mathrm{N}$ responses (i.e., EONR values $<50 \mathrm{~kg} \mathrm{~N}^{-1}$ and EONR values $>200 \mathrm{~kg} \mathrm{~N} \mathrm{ha}^{-1}$ ) and therefore improved the $r^{2}$ values. The elastic net did well at adjusting recommendations for sites with moderate $\mathrm{N}$ responses (i.e., EONR values that ranged between 50 and $200 \mathrm{~kg} \mathrm{~N} \mathrm{ha}{ }^{-1}$ ). This resulted in only a minor improvement to $r^{2}$ values but, for many tools, increased the cEONR values compared to the decision tree (Table 4).

Contrasting the two modeling approaches by examining linear regression slopes of tools' recommendations to EONR (Figures 6-8) statistically showed 8 of the 21 decision tree 


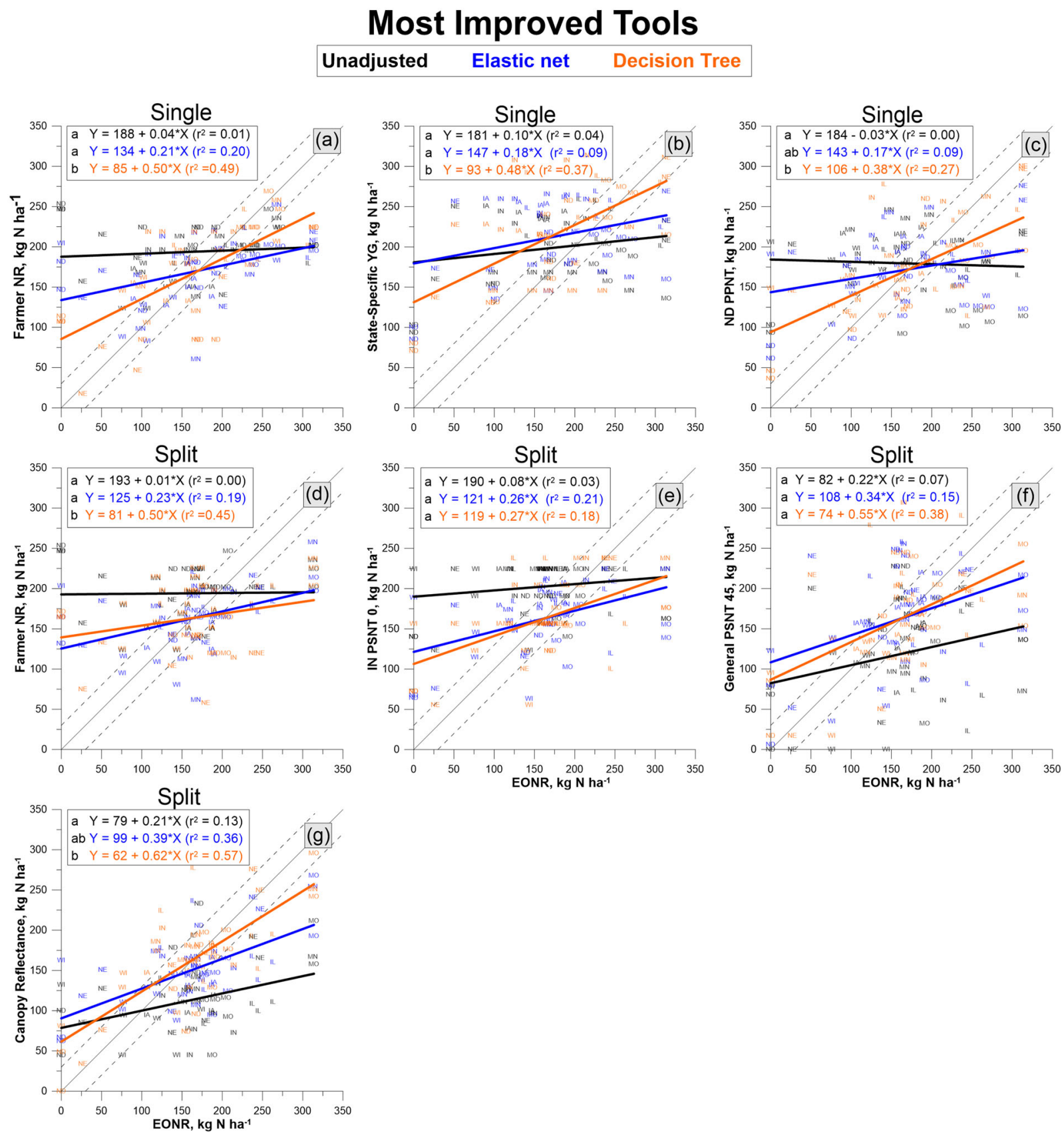

F I G U R E 6 "Most improved" N recommendation tool improvement (i.e., best improvement of performance metrics across elastic net and decision tree models) for predicting the economically optimal $\mathrm{N}$ rate (EONR) after adjusting with soil and weather measurements. Comparison of before (black labels and lines) and after adjusting for soil and weather information using an elastic net regression (blue labels and lines) or recursive partitioning decision trees (orange labels and lines). Linear regression equations and their coefficient of variance are shown with significant differences between slopes identified with letters at the beginning of each equation. The 1:1 line is an indicator of a perfect predictor of EONR. The dashed lines represent the area in which tools were within $\pm 30 \mathrm{~kg} \mathrm{~N} \mathrm{ha}^{-1}$ of EONR or relatively close to EONR. Tools were used for a "single" (at-planting) or a "split" (at-planting + sidedress) N application

tools improved ( $P$ values $\leq .05)$, giving a relationship closer to the 1:1 line. Six of these eight decision tree adjustments were significantly improved over the elastic net adjustments (Figure 6A-E; Figure 7A, 7B, and 7E). Whereas no elastic net improvement was significant compared to the unadjusted tools.
Both algorithms pointed to similar soil and weather measurements when adjusting $\mathrm{N}$ recommendations tools, reinforcing the legitimacy of these modeling tools. The most common measurements used by both algorithms were $\mathrm{AWDR}_{30-\mathrm{P}}$, soil pH (0-0.30 m), and BD (0-0.30 m) (Table 5 and Figures 4 and 5). Only in three cases did the decision tree 


\section{Moderately Improved Tools}

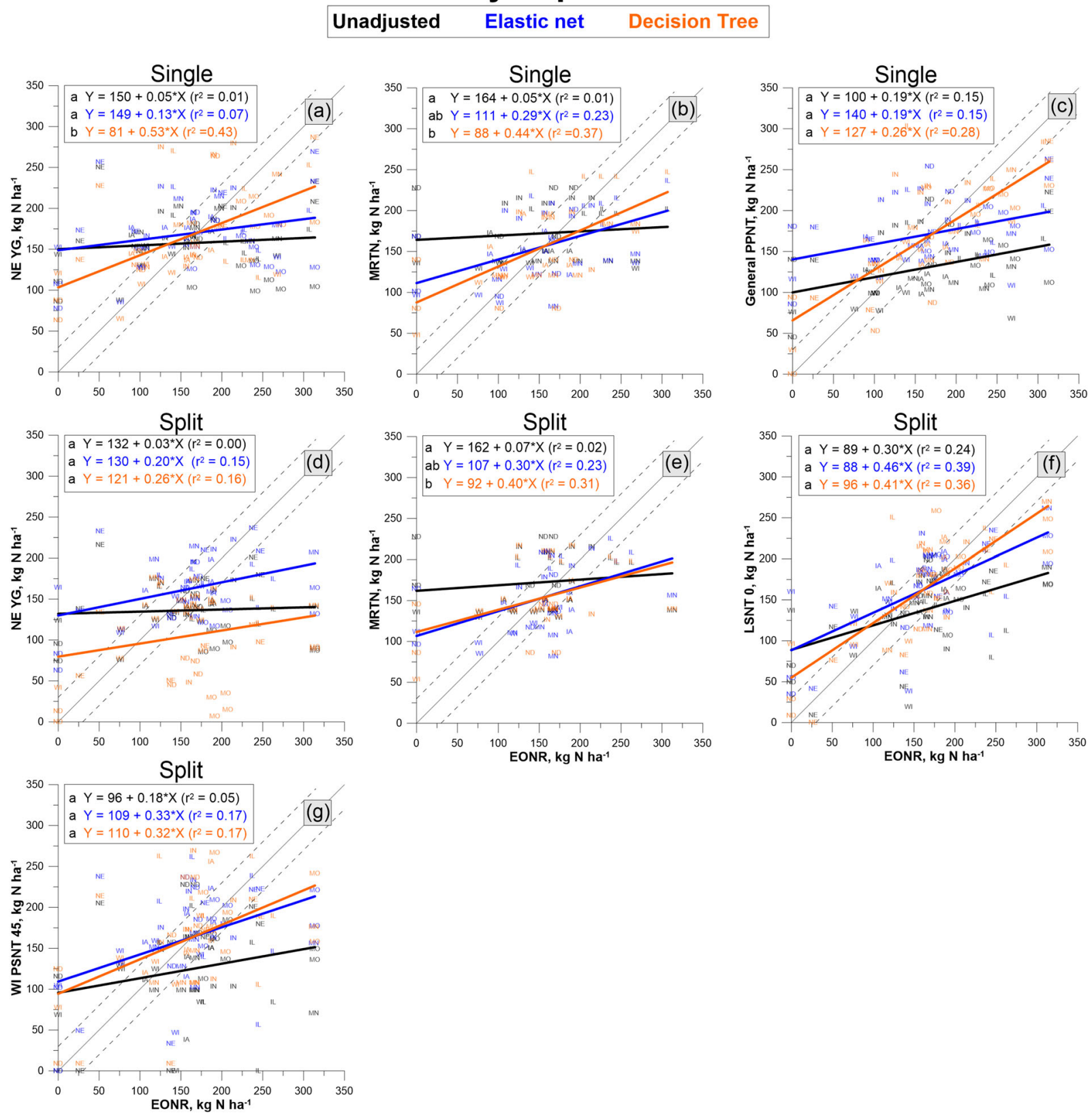

F I G U R E 7 "Moderately improved" N recommendation tool improvement (i.e., good but inconsistent improvement of performance metrics across elastic net and decision tree models) for predicting the economically optimal nitrogen rate (EONR) after adjusting with soil and weather measurements. Comparison of before (black labels and lines) and after adjusting for soil and weather information using an elastic net regression (blue labels and lines) or recursive partitioning decision trees (orange labels and lines). Linear regression equations and their coefficient of variance are shown with significant differences between slopes identified with letters at the beginning of each equation. The 1:1 line is an indicator of a perfect predictor of EONR. The dashed lines represent the area in which tools were within $\pm 30 \mathrm{~kg} \mathrm{~N}^{-1}$ of EONR or relatively close to EONR. Tools were used for a "single" (at-planting) or a "split" (at-planting + sidedress) N application

identify a measurement that was not used by the elastic net [single NebraSKA YG (percent clay) and split General PSNT 45 ( $\mathrm{PPT}_{\mathrm{P}-\mathrm{S}}$ and $\left.\left.\mathrm{BD}\right)\right]$. All other measurements identified as important in the decision tree were also used in the elastic net (Table 5 and Figures 4 and 5).

From a practical standpoint, decision tree adjustment outcomes were the most helpful as they used $\leq 3$ measurements in their adjustments, compared to up to 10 measurements with elastic net outcomes. Requiring more than one soil measurement to adjust tools will increase the cost (time and money) of using that tool. For example, the canopy reflectance sensor improved when using total inorganic $\mathrm{C}$, organic matter, $\mathrm{pH}$, bulk density, silt, and total C. The cost of soil sampling (at multiple soil depths) and laboratory analyzes for 


\section{Least Improved Tools}
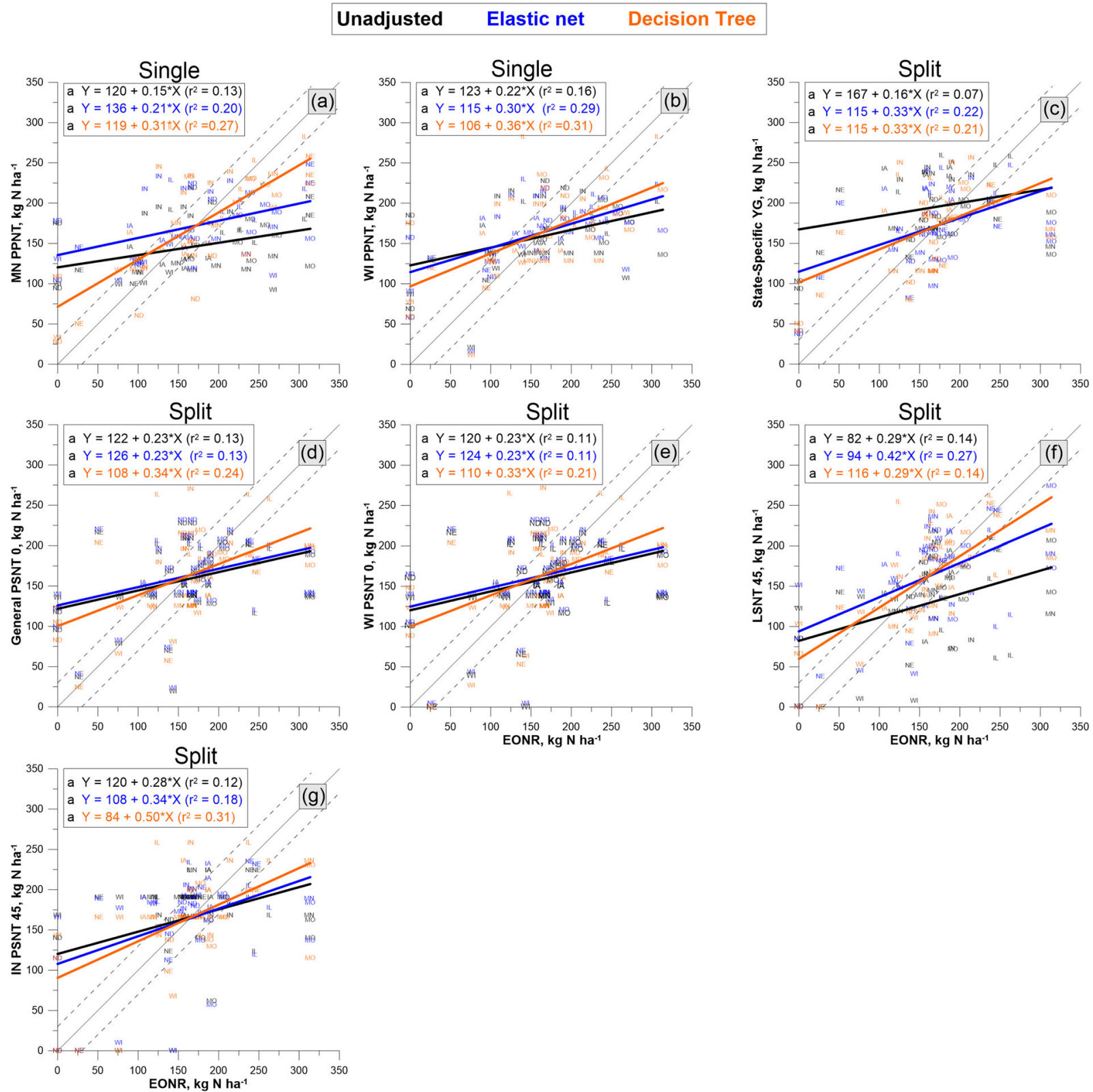

F I G U R E 8 "Least improved" N recommendation tool improvement (i.e., poorest improvement to performance metrics across elastic net and decision tree models) for predicting the economically optimal nitrogen rate (EONR) after adjusting with soil and weather measurements.

Comparison of before (black labels and lines) and after adjusting for soil and weather information using an elastic net regression (blue labels and lines) or recursive partitioning decision trees (orange labels and lines). Linear regression equations and their coefficient of variance are shown with significant differences between slopes identified with letters at the beginning of each equation. The 1:1 line is an indicator of a perfect predictor of EONR. The dashed lines represent the area in which tools were within $\pm 30 \mathrm{~kg} \mathrm{~N} \mathrm{ha}^{-1}$ of EONR or relatively close to EONR. Tools were used for a "single" (at-planting) or a "split" (at-planting + sidedress) N application

multiple places across a field is impractical and cost prohibitive. Comparably, the decision tree adjustment for the canopy reflectance sensor only required BD and resulted in a remarkably better improvement over the elastic net adjustment. Bulk density is an inexpensive measurement and has become easier and more cost effective to get at a high spa- tial resolution with advancing precision agriculture technology (Brune et al., 2018). Furthermore, the decision tree approach did better at identifying sites with low $\mathrm{N}$ need and correctly decreasing $\mathrm{N}$ recommendations. This is critical for reducing overapplication of $\mathrm{N}$ and negative environmental outcomes. 


\section{5 | Tools improved enough?}

Improvement using soil and weather information was observed for many tools, but final performance metrics were inferior compared to what others have reported for some $\mathrm{N}$ recommendation tools. Tested against EONR values in Pennsylvania, the Pennsylvania PSNT was found to have a $r^{2}=.48$ (Schmidt et al., 2009). Using a dataset from New York, the Adapt-N crop growth model had a $r^{2}$ of .56 (Sela et al., 2017). Across multiple site-years within the U.S. Midwest, chlorophyll meter-derived $\mathrm{N}$ recommendations resulted in a strong linear relationship with EONR, with $r^{2}$ values that ranged between .53 and .76 (Scharf et al., 2006; Schmidt et al., 2009) A likely reason for our more modest results is that the sites represent a vast geographic area, and therefore represent extreme diversity in soil and weather environments (Kitchen et al., 2017). Most of these tools tested were developed or tailored from field research within a given U.S. state or subregion of the U.S. Midwest. Thus, testing the tool more extensively would be considered an "extrapolation". Since these tools were generally grounded in biophysical principles and agronomy, testing their utility throughout the region is warranted. But we conclude these tools are not very robust over broad environmental conditions, even with the soil and weather adjustments we considered, and that additional development of $\mathrm{N}$ fertilizer recommendations are needed.

\section{4 | CONCLUSIONS}

Two unique adjustment methods were used to show that $\mathrm{N}$ recommendation tools could be improved by incorporating measured soil and weather information. Results showed that incorporating soil and weather information was successful for most of the tools, but the tools improved to varying degrees. When tool recommendations overestimated EONR, improvements were generally made by adjusting with soil information, while recommendations that underestimated EONR were improved with weather information. When tools overestimated EONR (potentially not considering soil $\mathrm{N}$ supply) using soil measurements like $\mathrm{TC}$ and soil $\mathrm{pH}$ decrease recommendations closer to EONR. When tools underestimated EONR (excessive $\mathrm{N}$ loss) using weather information like SDI or AWDR helped increase recommendations closer to EONR. Using these improved tools at a regional level shows encouraging results and could improve farmers' profits and reduce $\mathrm{N}$ lost to the environment.

Even with the adjustments, however, these tools could still be further improved as the best linear relationship with EONR resulted in $r^{2}$ values $\leq .57$. This means most of the variability in EONR was not captured with $\mathrm{N}$ recommendation tools or with the studied adjustments. Additional improvements might occur by incorporating other soil, weather, or management measurements not used in our analysis that might better delineate $\mathrm{N}$ response. Therefore, predicting $\mathrm{N}$ need for a mature plant when the plant is not yet germinated or is only at about $\sim 20 \%$ of total dry matter of a mature plant will always be challenging when using a single, split, or sidedress application. Nitrogen rate recommendation tools will always have some uncertainty, and enhancements should be viewed as offering "suggestions" or "forecasts" of estimated corn $\mathrm{N}$ needs for the growing season. This research was not intended to introduce new tools for public use but showcase that tools could be improved by incorporating additional soil and weather information. These methods show promise but require validation using multi-year $\mathrm{N}$ response trials from the same locations to make certain recommendation adjustment can fully account for temporal variation.

\section{O R C I D}

Curtis J. Ransom (10) https://orcid.org/0000-0002-1268-7247

Newell R. Kitchen (1) https://orcid.org/0000-0003-2268-9016

James J. Camberato (1) https://orcid.org/0000-0002-6677-

$854 \mathrm{X}$

Fabián G. Fernández @ https://orcid.org/0000-0002-9539-

0050

David W. Franzen (1D https://orcid.org/0000-0003-4862-8086

Emerson D. Nafziger (D https://orcid.org/0000-0002-6578-

1624

\section{R E F E R E N C E S}

Abendroth, L. J., Elmore, R. W., Boyer, M. J., \& Marley, S. K. (2011). Corn growth and development (Extension Publication PM 1009). Ames, IA: Iowa State University Extension.

Bandura, C. (2017). Agronomic and environmental evaluation of nitrogen rate and timing for midwestern corn production (Thesis, University of Wisconsin-Madison). https://search.library.wisc.edu/catalog/ 9912366352202121

Bean, G. M., Kitchen, N. R., Camberato, J. J., Ferguson, R. B., Fernandez, F. G., Franzen, D. W., Labosli, C. A. M., Nafziger, E. D., Sawyer, J. E., Scharf, P. C., Schepers, J., \& Shanahan, J. S. (2018). Improving an active-optical reflectance sensor algorithm using soil and weather information. Agronomy Journal, 110(6), 2541-2551. https://doi.org/10.2134/agronj2017.12.0733

Bootsma, A., Gamed, S., \& McKenney, D. W. (2005). Impacts of potential climate change on selected agroclimatic indices in Atlantic Canada. Canadian Journal of Soil Science, 85(2), 329-343. https://doi.org/10.4141/S04-019

Brouder, S. M., \& Mengel, D. B. (2003). The presidedress soil nitrate test for improving $\mathrm{N}$ management in corn. In Agronomy Guide (Purdue University Cooperative Extension Service AY-314-W). https://www. agry.purdue.edu/ext/pubs/ay-314-w.pdf (accessed 23 May 2016)

Brune, P. F., Ryan, B. J., Technow, F., \& Myers, D. B. (2018). Relating planter downforce and soil strength. Soil and Tillage Research, 184, 243-252. https://doi.org/10.1016/j.still.2018.08.003 
Buchholz, D. D., Brown, J. R., Crocker, D. K., Garrett, J. D., Hanson, R. G., Lory, J. A., Nathan, M. V., Scharf, P. C., \& Wheaton, H. N. (2004). Soil test interpretations and recommendations handbook. Columbia: University of Missouri-College of Agriculture, Division of Plant Science. aes.missouri.edu/pfcs/soiltest.pd (accessed 23 May 2016)

Bundy, L. G., Walters, D. T., \& Olness, A. E. (1999). Evaluation of soil nitrate tests for predicting corn nitrogen response in the North Central Region (North Central Regional Research Publication 342). Madison: Wisconsin Agriculture Experiment Station, University of Wisconsin.

Cassman, K. G. G., \& Munns, D. N. N. (1980). Nitrogen mineralization as affected by soil moisture, temperature, and depth. Soil Science Society of America Journal, 44(6), 1233-1237. https://doi.org/10.2136/ sssaj1980.03615995004400060020x

Cerrato, M. E., \& Blackmer, A. M. (1990). Comparison of models for describing; corn yield response to nitrogen fertilizer. Agronomy Journal, 82(1), 138-143. https://doi.org/10.2134/agronj1990. 00021962008200010030x

Clark, J. D., Veum, K. S., Fernández, F. G., Camberato, J. J., Carter, P. R., Ferguson, R. B., Franzen, D. W., Kaiser, D. E., Kitchen, N. R., Laboski, C. A. M., Nafziger, E. D., Rosen, C. J., Sawyer, J. E., \& Shanahan, J. F. (2019). United States Midwest soil and weather conditions influence anaerobic potentially mineralizable nitrogen. Soil Science Society of America Journal, 83(4), 1137-1147. https://doi.org/ 10.2136/sssaj2019.02.0047

Dinnes, D. L., Karlen, D. L., Jaynes, D. B., Kaspar, T. C., \& Hatfield, J. L. (2002). Review and interpretation: Nitrogen management strategies to reduce nitrate leaching in tile-drained midwestern soils. Agronomy Journal, 94(1), 153-171. https://doi.org/10.2134/agronj2002.0153

Fernández, F. G., Nafziger, E. D., Ebelhar, S. A., \& Hoeft, R. G. (2009). Managing nitrogen. In Illinois agronomy handbook (pp. 113-132). Urbana-Champaign: University of Illinois Cooperative Extension Service. https://extension.cropsci.illinois.edu/handbook/ pdfs/chapter09.pdf

Franzen, D. W. (2010). North Dakota fertilizer recommendation: Tables and equations. https://library.ndsu.edu/repository/handle/10365/ 9494 (accessed 23 May 2016).

Friedman, J., Hastie, T., \& Tibshirani, R. (2010). Regularization paths for generalized linear models via coordinate descent. Journal of Statistical Software, 33(1), 1-22. https://doi.org/10.18637/jss.v068.c02

Gelderman, R. H., \& Beegle, D. (1998). Nitrate-nitrogen. Recommended chemical soil test procedures for the North Central Region. Nathan, Manjula \& Gelderman, Ron, Recommended Chemical Soil Test Procedures for the North Central Region (pp. -, North Central Regional Research Publication No. 221 (Revised). Columnbia, MO: Missouri Agricultural Experiment Station SB 1001. https://extension.missouri. edu/media/wysiwyg/Extensiondata/Pub/pdf/specialb/sb1001.pdf

Gregorich, E. G., McLaughlin, N. B., Lapen, D. R., Ma, B. L., \& Rochette, P. (2014). Soil compaction, both an environmental and agronomic culprit: Increased nitrous oxide emissions and reduced plant nitrogen uptake. Soil Science Society of America Journal, 78(6), 1913-1923. https://doi.org/10.2136/sssaj2014.03.0117

Grömping, U. (2009). Variable importance assessment in regression: Linear regression versus random forest. American Statistician, 63(4), 308-319. https://doi.org/10.1198/tast.2009.08199

Hoeft, R. G., \& Peck, T. R. (1999). Picklesimer, Phyllis, Soil testing and fertility. Illinois Agronomy Handbook (pp. 78-116). UrbanaChampaign, IL: University of Illinois Extension.
Holland, K. H., \& Schepers, J. S. (2010). Derivation of a variable rate nitrogen application model for in-season fertilization of corn. Agronomy Journal, 102(5), 1415-1424. https://doi.org/10.2134/ agronj2010.0015

Hong, N., Scharf, P. C., Davis, J. G., Kitchen, N. R., \& Sudduth, K. A. (2007). Economically optimal nitrogen rate reduces soil residual nitrate. Journal of Environment Quality, 36(2), 354-362. https://doi.org/10.2134/jeq2006.0173

Kaiser, D. E., Fernandez, F., Lamb, J. A., \& Coulter, J. A. (2016). Fertilizing corn in Minnesota (University of Minnesota Extension Publication AG-FO-3790-D, Revised 2016). St. Paul, MN: University of Minnesota Extension. https://wrl.mnpals.net/islandora/object/ WRLrepository\%3A3034/datastream/PDF/view (accessed 30 Apr. 2018).

Kay, B. D., Mahboubi, A. A., Beauchamp, E. G., \& Dharmakeerthi, R. S. (2006). Integrating soil and weather data to describe variability in plant available nitrogen. Soil Science Society of America Journal, 70(4), 1210-1221. https://doi.org/10.2136/sssaj2005.0039

Kitchen, N. R., Shanahan, J. F., Ransom, C. J., Bandura, C. J., Bean, G. M., Camberato, J. J., Carter, P. R., Clark, J. D., Ferguson, R.B., Fernández, F. G., Franzen, D. W., Laboski, C. A. M., Nafziger, E. D., Qing, Z., Sawyer, J. E., \& Shafer, M. (2017). A public-industry partnership for enhancing corn nitrogen research and datasets: Project description, methodology, and outcomes. Agronomy Journal, 109(5), 2371-2388. https://doi.org/10.2134/agronj2017.04.0207

Kitchen, N. R., Sudduth, K. A., Drummond, S. T., Scharf, P. C., Palm, H. L., Roberts, D. F., \& Vories, E. D. (2010). Ground-based canopy reflectance sensing for variable-rate nitrogen corn fertilization. Agronomy Journal, 102(1), 71-84. https://doi.org/10.2134/ agronj2009.0114

Kuhn, M. (2017). Caret: Classification and regression training (R package version 6.0-76). https://doi.org/10.1126/science.1127647

Kyveryga, P. M., Blackmer, A. M., Ellsworth, J. W., \& Isla, R. (2004). Soil $\mathrm{pH}$ effects on nitrification of fall-applied anhydrous ammonia. Soil Science Society of America Journal, 68(2), 545-551. https://doi. org/10.2136/sssaj2004.0545

Kyveryga, P. M., Blackmer, A. M., \& Zhang, J. (2009). Characterizing and classifying variability in corn yield response to nitrogen fertilization on subfield and field scales. Agronomy Journal, 101(2), 269-277. https://doi.org/10.2134/agronj2008.0168x

Laboski, C. A. M., \& Peters, J. B. (2012). Nutrient application guidelines for field, vegetable, and fruit crops in Wisconsin. Madison, WI: Division of Cooperative Extension of the University of Wisconsin.

Lenth, R. (2018). Emmeans: Estimated marginal means, aka leastsquares means (r package version 1.3.1). https://cran.r-project.org/ package $=$ emmeans

Loh, W. Y. (2014). Classification and regression tree methods. Wiley StatsRef: Statistics Reference Online. Chichester, UK: John Wiley \& Sons, Ltd.

Maag, M., \& Vinther, F. (1996). Nitrous oxide emission by nitrification and denitrification in different soil types and at different soil moisture contents and temperatures. Applied Soil Ecology, 4(1), 5-14. https://doi.org/10.1016/0929-1393(96)00106-0

McDaniel, M. D., Walters, D. T., Bundy, L. G., Li, X., Drijber, R. A., Sawyer, J. E., Castellano, M. J., Laboski, C. A. M., Scharf, P. C., \& Horwath, W. R. (2020). Combination of biological and chemical soil tests best predict maize nitrogen response. Agronomy Journal, 112(2), 1263-1278. https://doi.org/10.1002/agj220627.20129 
Melkonian, J. J., van Es, H. M., DeGaetano, A. T., \& Joseph, L. (2008). ADAPT-N: Adaptive nitrogen management for maize using highresolution climate data and model simulations. In R. Kosla (Ed.), Proceedings of the 9th International Conference on Precision Agriculture, 20-23 July 2008, Denver, CO Monticello, IL: Proceedings paper. Published by the International Society of Precision Agriculture.

Melkonian, J., van Es, H., DeGaetano, A., Sogbedji, J., \& Joseph, L. (2007). Application of dynamic simulation modeling for nitrogen management in maize. In Bruulsema, T, Managing crop nutrition for weather (pp. 14-22). Peachtree Corners, GA: International Plant Nutrition Institute Publishing.

Miao, Y., Mulla, D. J., \& Robert, P. C. (2006). Identifying important factors influencing corn yield and grain quality variability using artificial neural networks. Precision Agriculture, 7(2), 117-135. https://doi.org/10.1007/s11119-006-9004-y

Moebius-Clune, B., van Es, H., \& Melkonian, J. (2013). Adapt-N uses models and weather data to improve nitrogen management for corn. Better Crops, 97(4), 7-9.

Morris, T. F., Murrell, T. S., Beegle, D. B., Camberato, J. J., Ferguson, R. B., Grove, J., Ketterings, Q., Kyveryga, P. M., Laboski, C. A. M., McGrath, J. M., Meisinger, J. M., Melkonian, J., MoebiusClune, B. N., Nafziger, E. D., Osmond, D., Sawyer, J. E., Scharf, P. C., Smith, W., Spargo, J. T., ..., Yang, H. (2018). Strengths and limitations of nitrogen rate recommendations for corn and opportunities for improvement. Agronomy Journal, 110(1), 1-37. https://doi.org/10.2134/agronj2017.02.0112

Nelson, D. W., \& Sommers, L. E. (1996). Total carbon, organic carbon, and organic matter. In D. L. Sparks, A. L. Page, P. A. Helmke, R. H. Loeppert, P. N. Soltanpour, M. A. Tabatabai, M. E. Sumner et al. (Eds.), Methods of soil analysis. Part 3: Chemical methods (pp. 9611010). Madison, WI: SSSA and ASA.

Nielsen, R. (2013). Root development in young corn. West Lafayette, IN: Corny News Network, Purdue Extension. https://www.agry.purdue. edu/ext/corn/news/timeless/roots

Passioura, J. B. (1991). Soil structure and plant growth. Australian Journal of Soil Research, 29(6), 717-728. https://doi.org/10.1071/ SR9910717

Puntel, L. A., Sawyer, J. E., Barker, D. W., Thorburn, P. J., Castellano, M. J., Moore, K. J., VanLoocke, A., Heaton, E. A., \& Archontoulis, S. V. (2018). A systems modeling approach to forecast corn economic optimum nitrogen rate. Frontiers in Plant Science, 9, 1-15. https://doi. org/10.3389/fpls.2018.00436

Ransom, C. J., Kitchen, N. R., Camberato, J. J., Carter, P. R., Ferguson, R. B., Fernández, F. G., Franzen, D. W., Laboski, C. A. M., Nafziger, E. D., Sawyer, J. E., Scharf, P. C., \& Shanahan, J. F. (2019). Statistical and machine learning methods evaluated for incorporating soil and weather into corn nitrogen recommendations. Computers and Electronics in Agriculture, 164, 104872. https://doi.org/10.1016/ j.compag.2019.104872

Ransom, C. J., Kitchen, N. R., Camberato, J. J., Carter, P. R., Ferguson, R. B., Fernández, F. G., Franzen, D. W., Laboski, C. A. M., Nafziger, E. D., Sawyer, J. E., Scharf, P. C., \& Shanahan, J. F. (2020). Corn nitrogen rate recommendation tools' performance across eight US Midwest Corn Belt states. Agronomy Journal, 112, 470-492. https://doi.org/10.1002/agj220627.20035

R Core Team. (2016). R: A language and environment for statistical computing. R Foundation for Statistical Computing, Vienna, Austria. http://www.R-project.org
Sawyer, J. E., \& Mallarino, A. P. (2017). Use of the late-spring soil nitrate test in Iowa corn production. https://store.extension.iastate. edu/Product/5259 (accessed 5 May 2018)

Sawyer, J., Nafziger, E., Randall, G. W., Bundy, L., Rehm, G., \& Joern, N. (2006). Concepts and rationale for regional nitrogen rate guidelines for corn concepts and rationale for regional nitrogen rate guidelines for corn. Ames, IA: Iowa State University, University Extension.

Scharf, P. C., Brouder, S. M., \& Hoeft, R. G. (2006). Chlorophyll meter readings can predict nitrogen need and yield response of corn in the north-central USA. Agronomy Journal, 98(3), 655-665. https://doi. org/10.2134/agronj2005.0070

Scharf, P. C., Kitchen, N. R., Sudduth, K. A., Davis, J. G., Hubbard, V. C., \& Lory, J. A. (2005). Field-scale variability in optimal nitrogen fertilizer rate for corn. Agronomy Journal, 97(2), 452-461. https:// doi.org/10.2134/agronj2005.0452

Schmidt, J. P., Dellinger, A. E., \& Beegle, D. B. (2009). Nitrogen recommendations for corn: An on-the-go sensor compared with current recommendation methods. Agronomy Journal, 101(4), 916-924. https://doi.org/10.2134/agronj2008.0231x

Schmitt, M. A., Randall, G. W., \& Beegle, D. B. (2002). A soil nitrogen test option for $n$ recommendations with corn. University of Minnesota Extension Service. http://www.extension. umn.edu/agriculture/nutrient-management/nitrogen/soil-nitrogentest-option-for-n-recommendations/ (accessed 23 May 2016).

Schröder, J., Neeteson, J. J., Oenema, O., \& Struik, P. C. (2000). Does the crop or the soil indicate how to save nitrogen in maize production? Field Crops Research, 66(2), 151-164. https://doi.org/10.1016/ S0378-4290(00)00072-1

Sela, S., van Es, H. M., Moebius-Clune, B. N., Marjerison, R., MoebiusClune, D., Schindelbeck, R., \& Young, E. (2017). Dynamic model improves agronomic and environmental outcomes for maize nitrogen management over static approach. Journal of Environment Quality, 46(2), 311-319. https://doi.org/10.2134/jeq2016.05.0182

Shanahan, J. F., Kitchen, N. R., Raun, W. R., \& Schepers, J. S. (2008). Responsive in-season nitrogen management for cereals. Computers and Electronics in Agriculture, 61(1), 51-62. https://doi.org/10.1016/ j.compag.2007.06.006

Shapiro, C. A., Ferguson, R. B., Hergert, G. W., Wortmann, C. S., \& Walters, D. T. (2008). Fertilizer suggestions for corn (pp. -, EC117). Lincoln, NE: University of Nebraska-Lincoln Extension. https://agronomy.unl.edu/faculty/ferguson/ec117.pdf.

Šimek, M., \& Cooper, J. E. (2002). The influence of soil pH on denitrification: Progress towards the understanding of this interaction over the last 50 years. European Journal of Soil Science, 53(3), 345-354. https://doi.org/10.1046/j.1365-2389.2002.00461.x

Sogbedji, J., van Es, H., Klausner, S., Bouldin, D., \& Cox, W. (2001). Spatial and temporal processes affecting nitrogen availability at the landscape scale. Soil and Tillage Research, 58(3-4), 233-244. https://doi.org/10.1016/S0167-1987(00)00171-9

Soil Survey Staff. (2014) Kellogg soil survey laboratory methods manual. Burt, Rebecca, Soil Survey Investigations Report No. 42, version 5.0. Lincoln, Nebraska: USDA-NRCS. https://www.nrcs.usda. gov/Internet/FSE_DOCUMENTS/stelprdb1253872.pdf

Tao, H., Morris, T. F., Kyveryga, P., \& McGuire, J. (2018). Factors affecting nitrogen availability and variability in cornfields. Agronomy Journal, 110(5), 1974-1986. https://doi.org/10.2134/agronj2017.11.0631.

Therneau, T., \& Atkinson, B. (2019). Rpart: Recursive partitioning and regression trees. https://cran.r-project.org/package=rpart 
Tremblay, N., Bouroubi, Y. M., Bélec, C., Mullen, R. W., Kitchen, N. R., Homason, W. E., Ebelhar, S., Mengel, D. B., Raun, W. R., Francis, D. D., Vories, E. D., \& Ortiz-Monasterio, I. (2012). Corn response to nitrogen is influenced by soil texture and weather. Agronomy Journal, 104(6), 1658-1671. https://doi.org/10.2134/agronj2012.0184

Vitosh, M. L., Johnson, J. W., \& Mengel, D. B. (1995). Tri-state fertilizer recommendations for corn, soybeans, wheat and alfalfa (Extension Bulletin E-2567). 2567, East Lansing, MI: Michigan State University Extension, - . http://archive.lib.msu.edu/DMC/Ag.\%20Ext.\%202007Chelsie/PDF/e2567.pdf

Voss, R. D., \& Killorn, R. (1988). General guide for fertilizer recommendations in Iowa (Publication AG-65). Ames, Iowa: Iowa State University Cooperative Extension Service.

Wilhelm, W. W., \& Wortmann, C. S. (2004). Tillage and rotation interactions for corn and soybean grain yield as affected by precipitation and air temperature. Agronomy Journal, 96(2), 425-432. https://doi.org/10.2134/agronj2004.0425
Zhu, Q., Schmidt, J. P., Lin, H. S., \& Sripada, R. P. (2009). Hydropedological processes and their implications for nitrogen availability to corn. Geoderma, 154(1-2), 111-122. https://doi.org/10.1016/ j.geoderma.2009.10.004

Zou, H., \& Hastie, T. (2005). Regularization and variable selection via the elastic net. Journal of the Royal Statistical Society: Series B (Statistical Methodology), 67(2), 301-320. https://doi.org/10.1111/j. 1467-9868.2005.00503.

How to cite this article: Ransom CJ, Kitchen NR, Sawyer JE, et al. Improving publicly available corn nitrogen rate recommendation tools with soil and weather measurements. Agronomy Journal. 2021;1-23. https://doi.org/10.1002/agj2.20627 